\title{
Molecular composition and volatility of isoprene photochemical oxidation secondary organic aerosol under low- and high-NO${ }_{x}$ conditions
}

\author{
Emma L. D’Ambro ${ }^{1,2}$, Ben H. Lee ${ }^{1}$, Jiumeng Liu ${ }^{3}$, John E. Shilling ${ }^{3,4}$, Cassandra J. Gaston ${ }^{1, a}$, \\ Felipe D. Lopez-Hilfiker ${ }^{1, b}$, Siegfried Schobesberger ${ }^{1}$, Rahul A. Zaveri ${ }^{3}$, Claudia Mohr $^{1, c}$, Anna Lutz ${ }^{5}$, \\ Zhenfa Zhang $^{6}$, Avram Gold ${ }^{6}$, Jason D. Surratt ${ }^{6}$, Jean C. Rivera-Rios ${ }^{7}$, Frank N. Keutsch ${ }^{7}$, and Joel A. Thornton ${ }^{1,2}$ \\ ${ }^{1}$ Department of Atmospheric Sciences, University of Washington, Seattle, WA 98195, USA \\ ${ }^{2}$ Department of Chemistry, University of Washington, Seattle, WA 98195, USA \\ ${ }^{3}$ Atmospheric Sciences and Global Change Division, Pacific Northwest National Laboratory, Richland, WA 99352, USA \\ ${ }^{4}$ Environmental Molecular Sciences Laboratory, Pacific Northwest National Laboratory, Richland, WA 99352, USA \\ ${ }^{5}$ Department of Chemistry, Atmospheric Science, University of Gothenburg, Gothenburg, Sweden \\ ${ }^{6}$ Department of Environmental Sciences and Engineering, Gillings School of Global and Public Health, \\ University of North Carolina, Chapel Hill, NC 27599, USA \\ ${ }^{7}$ John A. Paulson School of Engineering and Applied Sciences and Department of Chemistry and Chemical Biology, Harvard \\ University, Cambridge, MA, USA \\ ${ }^{a}$ now at: Rosenstiel School of Marine \& Atmospheric Science, University of Miami, FL 33149, USA \\ ${ }^{b}$ now at: Laboratory of Atmospheric Chemistry, Paul Scherrer Institute, Zurich, Switzerland \\ ${ }^{c}$ now at: Institute of Meteorology and Climate Research, Karlsruhe Institute of Technology, Karlsruhe, Germany
}

Correspondence to: Joel A. Thornton (thornton@atmos.uw.edu)

Received: 28 July 2016 - Published in Atmos. Chem. Phys. Discuss.: 8 August 2016

Revised: 23 November 2016 - Accepted: 5 December 2016 - Published: 4 January 2017

\begin{abstract}
We present measurements of secondary organic aerosol (SOA) formation from isoprene photochemical oxidation in an environmental simulation chamber at a variety of oxidant conditions and using dry neutral seed particles to suppress acid-catalyzed multiphase chemistry. A highresolution time-of-flight chemical ionization mass spectrometer (HR-ToF-CIMS) utilizing iodide-adduct ionization coupled to the Filter Inlet for Gases and Aerosols (FIGAERO) allowed for simultaneous online sampling of the gas and particle composition. Under high- $\mathrm{HO}_{2}$ and low-NO conditions, highly oxygenated $(\mathrm{O}: \mathrm{C} \geq 1) \mathrm{C}_{5}$ compounds were major components $(\sim 50 \%)$ of SOA. The SOA composition and effective volatility evolved both as a function of time and as a function of input NO concentrations. Organic nitrates increased in both the gas and particle phases as input NO increased, but the dominant non-nitrate particle-phase components monotonically decreased. We use comparisons of measured and predicted gas-particle partitioning of individual
\end{abstract}

components to assess the validity of literature-based groupcontribution methods for estimating saturation vapor concentrations. While there is evidence for equilibrium partitioning being achieved on the chamber residence timescale $(5.2 \mathrm{~h})$ for some individual components, significant errors in groupcontribution methods are revealed. In addition, $>30 \%$ of the SOA mass, detected as low-molecular-weight semivolatile compounds, cannot be reconciled with equilibrium partitioning. These compounds desorb from the FIGAERO at unexpectedly high temperatures given their molecular composition, which is indicative of thermal decomposition of effectively lower-volatility components such as larger molecular weight oligomers. 


\section{Introduction}

Atmospheric aerosol particles reduce visibility, adversely affect human health, and have uncertain overall effects on global climate (Pöschl, 2005), with particles smaller than $1 \mu \mathrm{m}$ in diameter playing important roles. Submicron particles typically contain a significant fraction of organic material, on the order of 20-90\% (Jimenez et al., 2009; Zhang et al., 2007). Particulate organic material can be emitted directly to the atmosphere, known as primary organic aerosol, or formed from the gas-to-particle conversion of volatile organic compound (VOC) oxidation products, which can partition (Donahue et al., 2011; Riipinen et al., 2011) or react heterogeneously (Docherty et al., 2005; Gaston et al., 2014; Jang et al., 2002; Surratt et al., 2006, 2007) on existing particles or homogeneously nucleate to form new particles (Kirkby et al., 2016). This condensed phase organic material arising from gas-to-particle conversion is known as secondary organic aerosol (SOA).

Biogenic VOCs (BVOCs) contribute significantly to SOA. Emitted at rates of $500 \mathrm{TgC} \mathrm{yr}^{-1}$ (Guenther et al., 2012) and with a high reactivity, isoprene $\left(\mathrm{C}_{5} \mathrm{H}_{8}\right)$ has the potential to contribute substantially to SOA, even if the overall conversion is inefficient. Initially, the observed products of isoprene oxidation were of high volatility, which led to the hypothesis that isoprene did not generate SOA (Pandis et al., 1991). However, subsequent chamber experiments showed that the yield of SOA from isoprene photochemical oxidation can range from $<1$ to $29 \%$, with the highest yields achieved either with acidic aqueous seed particles (Surratt et al., 2010) or as a transient during successive oxidative aging (Kroll et al., 2006). Chemically speciated measurements of atmospheric aerosol components in an isoprene-rich environment identified polyol compounds likely formed from isoprene oxidation (Claeys et al., 2004; Paulot et al., 2009b). Subsequent chamber studies have shown that, under low-NO conditions, isoprene reacts with $\mathrm{OH}$ followed by $\mathrm{HO}_{2}$ to form a hydroxy hydroperoxide, ISOPOOH, which further reacts with $\mathrm{OH}$ to form the isoprene epoxy diol, IEPOX (see Scheme 1) (Paulot et al., 2009a, b). Both laboratory and field studies suggest that IEPOX plays an important role in the formation of isoprene SOA (iSOA) via acid-catalyzed heterogeneous reactions on deliquesced particles (Gaston et al., 2014; Lin et al., 2012, 2013a, b, 2014; Paulot et al., 2009b; Surratt et al., 2006, 2010). In the absence of acidic seed particles, iSOA yields have generally been low, but functional group analyses suggest a significant contribution of peroxide moieties and a complex dependence upon $\mathrm{NO}_{x}$ (Dommen et al., 2006; King et al., 2010; Kroll et al., 2005, 2006; Sato et al., 2011; Xu et al., 2014; Zhang et al., 2011). Despite these advances, a comprehensive molecular characterization of photochemical iSOA has been lacking.

Much attention has been focused on the formation of SOA derived from IEPOX chemistry; however, understanding the formation of SOA from pathways other than IEPOX is im-

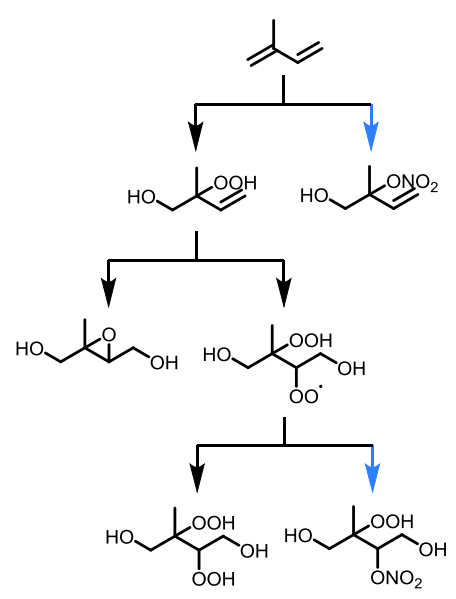

Scheme 1. A simplified schematic of isoprene and its major oxidation products. Products formed in the presence of $\mathrm{NO}_{x}$ are identified with blue arrows.

portant for quantifying SOA in environments where SOA is likely formed via other mechanisms due to the lack of acidic seed. Three recent studies performed photochemical oxidation on either ISOPOOH (Krechmer et al., 2015; Riva et al., 2016) or both isoprene and ISOPOOH (Liu et al., 2016) in the absence of wet acidic seed in order to study the mechanism of iSOA formation when the IEPOX pathway is suppressed. These studies identified several $\mathrm{C}_{5} \mathrm{H}_{8-12} \mathrm{O}_{4-8}$ compounds in both the gas (Krechmer et al., 2015) and particle (Liu et al., 2016; Riva et al., 2016) phases. Liu et al. (2016) found that under the photochemical conditions of their chamber, the most abundant compound in the particle phase was $\mathrm{C}_{5} \mathrm{H}_{12} \mathrm{O}_{6}$, ISOP $(\mathrm{OOH})_{2}$, presumed to be a dihydroxy dihydroperoxide formed from the reaction of an organic peroxy radical $\left(\mathrm{RO}_{2}\right)$ derived from ISOPOOH $+\mathrm{OH}$ followed by further reaction with hydroperoxy radicals $\left(\mathrm{HO}_{2}\right)$ (see Scheme 1) (Liu et al., 2016). However, the iSOA yields starting from isoprene reported by Liu et al. (2016) were substantially higher than those starting from ISOPOOH alone as reported by Krechmer et al. (2015), and they were generally higher than most previous iSOA studies in the absence of deliquesced acidic seed particles (Dommen et al., 2006; King et al., 2010; Xu et al., 2014; Nguyen et al., 2015).

Furthermore, there is significant interest in understanding how anthropogenic pollutants affect SOA yields (Shilling et al., 2013; Weber et al., 2007; Xu et al., 2015), and there have been several chamber studies to understand the role of $\mathrm{NO}_{x}$ specifically in iSOA yields (Dommen et al., 2006; King et al., 2010; Kroll et al., 2005, 2006; Xu et al., 2014; Zhang et al., 2011). The general effect of $\mathrm{NO}_{x}$ on the newly discovered non-IEPOX SOA system was described previously (Liu et al., 2016). The total SOA mass concentration was shown to be stable for input NO concentrations from 0-20 ppb, with a sharp decrease in SOA mass concentration at the highest input NO concentration $(50 \mathrm{ppb})$. While these studies have ad- 
vanced our knowledge of the possible mechanisms of iSOA formation, in order to more accurately assess the environments in which this pathway will operate, it remains important to further quantify (a) the branching between the formation of the $\mathrm{C}_{5} \mathrm{H}_{11} \mathrm{O}_{6}$ peroxy radical versus the formation of IEPOX from the reaction between ISOPOOH and $\mathrm{OH}$, (b) the fate of the $\mathrm{C}_{5} \mathrm{H}_{11} \mathrm{O}_{6}$ peroxy radical under various environmental conditions, as well as (c) the volatility of the SOA formed under various environmental conditions, and (d) the role of the broader suite of oxidation products in the formation of this non-IEPOX SOA.

We present laboratory chamber studies of the gas- and particle-phase composition resulting from both the low- and high- $\mathrm{NO}_{x}$ photochemical oxidation of isoprene with the goal of better understanding the chemical mechanisms of iSOA formation and the evolution of its volatility and composition over time, specifically points (c) and (d) above. We compare the observed gas-particle partitioning of several oxidation products to an assumption of equilibrium partitioning theory. In this analysis, we use the measured thermograms of particle-phase components to assess commonly used groupcontribution methods for estimating saturation vapor concentrations, $C^{*}$. Moreover, we use a combined compositionvolatility framework (Lopez-Hilfiker et al., 2015) to quantify the presence of more refractory oligomer-like components of SOA. From these analyses we find (i) that the direct effect of higher $\mathrm{NO}_{x}$ (i.e., all else being constant) is a suppression of iSOA yields at very high input NO concentrations (50 ppb); (ii) a large shift to more refractory components and $\mathrm{N}$-containing products with increasing $\mathrm{NO}_{x}$; and (iii) a generally important role for oligomerization reactions and other multiphase chemistry irrespective of $\mathrm{NO}_{x}$ concentrations, even at relatively low precursor concentrations, likely involving a broad suite of isoprene oxidation products.

\section{Experimental methods}

\subsection{Chamber operation}

Experiments were performed in the Pacific Northwest National Laboratory's (PNNL) $10.6 \mathrm{~m}^{3}$ polytetrafluoroethylene (PTFE) environmental chamber. The chamber has been described in detail elsewhere (Liu et al., 2012), and a portion of the data discussed herein were obtained from the same experiments described in Liu et al. (2016). Additional experiments with identical chamber operation were conducted to examine a wider range of oxidant conditions. The chamber was primarily operated in continuous-flow mode where reactants were continuously delivered at a constant rate to allow reaction precursors and products to reach steady-state concentrations (Shilling et al., 2008). The extent of reaction is controlled by oxidant concentrations and the residence time of air within the chamber, typically $5.2 \mathrm{~h}$. We also discuss a time-dependent "batch mode" experiment also performed during 2015 for comparison purposes, where the chamber is filled with a fixed amount of isoprene and oxidant precursors in the dark and then the chemistry is followed for $\sim 6 \mathrm{~h}$ after turning on the UV-VIS lights.

Isoprene was delivered into the chamber via a calibrated cylinder (Matheson, $20 \mathrm{ppm}$ in nitrogen) and mass flow controller. $\mathrm{OH}$ radicals were generated by the photolysis of $\mathrm{H}_{2} \mathrm{O}_{2}$. An aqueous solution of $\mathrm{H}_{2} \mathrm{O}_{2}$ was introduced into the chamber via an automated syringe operated at various flow rates to achieve a range of $\mathrm{H}_{2} \mathrm{O}_{2}$, and therefore $\mathrm{OH}$ and $\mathrm{HO}_{2}$, concentrations. Quasi-monodispersed, effloresced $50 \mathrm{~nm}$ diameter solid ammonium sulfate seed particles were continually added to facilitate the partitioning of oxidized VOC onto particle surfaces as opposed to chamber walls (Zhang et al., 2014) for the formation of SOA. When desired, NO was added via a calibrated cylinder (Matheson, $500 \mathrm{ppm}$ in nitrogen) and mass flow controller. During the continuousflow experiments relative humidity (RH) was controlled to $\sim 50 \%$, while the batch mode experiment was performed under dry conditions $(\sim 10 \% \mathrm{RH})$.

\subsection{Instrumentation}

A suite of online instruments were utilized to monitor gasand particle-phase composition. Ozone and $\mathrm{NO} / \mathrm{NO}_{2} / \mathrm{NO}_{x}$ concentrations were measured using commercial instruments (Thermo Environmental Instruments models 49C and $42 \mathrm{C}$, respectively). Aerosol number and volume concentrations were measured with a scanning mobility particle sizer (SMPS, TSI model 3936). An Aerodyne high-resolution time-of-flight aerosol mass spectrometer (HR-ToF-AMS) monitored bulk submicron organic and inorganic aerosol composition. The evolution of isoprene was monitored with an Ionicon proton-transfer-reaction mass spectrometer (PTRMS).

A high-resolution time-of-flight chemical ionization mass spectrometer (HR-ToF-CIMS) using iodide-adduct ionization as described previously (B. H. Lee et al., 2014) was coupled to a Filter Inlet for Gases and Aerosols (FIGAERO) (Lopez-Hilfiker et al., 2014) for measuring a suite of oxygenated products in the gas and particle phases. The HR-ToFCIMS provides measurements of molecular composition, although it cannot provide structural information and therefore cannot differentiate between isobaric compounds. Briefly, the FIGAERO is an inlet manifold that allowed for measurement of both gas- and particle-phase molecular composition with approximately hourly time resolution. To collect particles, chamber air was drawn through a $1.27 \mathrm{~cm}$ OD (2014) or $0.635 \mathrm{~cm}$ OD (2015) stainless steel tube at $2.5 \mathrm{slpm}$ across a Teflon filter (Zefluor ${ }^{\circledR} 24 \mathrm{~mm}$ diameter, $2.0 \mu \mathrm{m}$ pore size, Pall Corp.) for 31 (2014), 42 (2015), or 25 (batch) min. Through a separate inlet chamber air was simultaneously sampled at $22 \mathrm{slpm}$ (2014) or $12 \mathrm{slpm}$ (2015) through a $1.9 \mathrm{~cm} \mathrm{OD,} 2 \mathrm{~m}$ long (2014), or $1.1 \mathrm{~m}$ long (2015), PTFE tube for gas-phase analysis. The gas-phase analysis required sub-sampling of 
a portion of the flow after dilution to maintain linearity of response in the chemical ionization. After a particle collection period, gas-phase analysis ended and the filter containing collected particles was actuated to a location downstream of an ultra-high-purity (UHP) $\mathrm{N}_{2}$ source and immediately upstream of an orifice into the HR-ToF-CIMS. UHP $\mathrm{N}_{2}$, continually passed across the filter at $2.5 \mathrm{slpm}$, was heated at a rate of 10 or $15^{\circ} \mathrm{C} \mathrm{min}^{-1}$ to $200^{\circ} \mathrm{C}$ for a temperatureprogrammed thermal desorption and then kept at $200^{\circ} \mathrm{C}$ for the remainder of the desorption time $(60 \mathrm{~min}$ total 2014 , $70 \mathrm{~min} 2015$, $40 \mathrm{~min}$ batch). The coupled FIGAERO-HRToF-CIMS will be referred to hereafter as the FIGAEROCIMS. The temperature axis of the FIGAERO thermograms was calibrated using compounds with known enthalpies of sublimation (Lopez-Hilfiker et al., 2014). Lopez-Hilfiker et al. (2014) showed that pure compounds, or mixtures of noninteracting compounds, have consistent thermogram shapes throughout time and reach a maximum signal at characteristic temperature $\left(T_{\max }\right)$, which can be related to their enthalpies of sublimation and therefore sub-cooled pure component vapor pressures. In this way, the $T_{\max }$ of detected compounds can be used to estimate their $C^{*}$ at ambient conditions even if the structure is unknown.

\subsection{Experimental overview}

Figure 1 presents a time series of all steady-state experiments. The left and right columns contain experiments conducted in May of 2014 and 2015, respectively. The top panels show the input concentrations of isoprene, hydrogen peroxide, and $\mathrm{NO}$, as well as the isoprene and $\mathrm{C}_{5} \mathrm{H}_{10} \mathrm{O}_{3}$ (ISOPOOH + IEPOX) concentrations measured at the chamber output. The phrases "input NO", "input $\mathrm{H}_{2} \mathrm{O}_{2}$ ", and "input isoprene" refer to the concentration of precursor that was in the chamber if there were no loss mechanisms except for dilution. For example, in Fig. 1, top, the input isoprene (dashed green line) is flat, while the amount of isoprene remaining in the chamber, i.e., what is measured with the PTR-MS (solid green line), varies depending on the chamber chemical environment. Thus, while we state that we input $0-50 \mathrm{ppb}$ NO in the chamber, in reality steady-state NO concentrations in the chamber are much lower for the majority of the chamber residence time. In fact, they are usually below the detection limit of the NO analyzer due to loss mechanisms such as photochemical conversion to $\mathrm{NO}_{2}$ and nitrate formation.

In Fig. 1 (top row) we show the time series of gas-phase species: input concentrations of isoprene, which were generally similar across both years ( 26 ppbv 2014,20 ppbv 2015); $\mathrm{NO} ; \mathrm{H}_{2} \mathrm{O}_{2}$; gas-phase measurements of the isoprene remaining in the chamber; and $\mathrm{C}_{5} \mathrm{H}_{10} \mathrm{O}_{3}$. As discussed above, the HR-ToF-CIMS cannot differentiate isobaric compounds and thus $\mathrm{C}_{5} \mathrm{H}_{10} \mathrm{O}_{3}$ represents the sum of ISOPOOH and IEPOX. It is important to note that while we are suppressing the uptake of IEPOX into the particle phase, it is still produced at a yield of about $70-80 \%$ (St. Clair et al., 2016) from the reaction of ISOPOOH $+\mathrm{OH}$. The middle row shows the organic aerosol (OA) as measured by the AMS, with the AMS blanks highlighted in black squares. Steady-state periods for analysis were determined by an unchanging OA concentration over a period of $2 \mathrm{~h}$ or more typically at least $24 \mathrm{~h}$ after an intentional change in experimental conditions. The bottom panels show the time series of a few dominant particle-phase components as measured by the FIGAEROCIMS: $\mathrm{C}_{5} \mathrm{H}_{12} \mathrm{O}_{6}, \mathrm{C}_{5} \mathrm{H}_{12} \mathrm{O}_{5}$, and $\mathrm{C}_{5} \mathrm{H}_{11} \mathrm{NO}_{7}$. The organic nitrate is scaled by a factor of 20 to show its time series on the same scale, although it is near zero when NO is not added to the chamber. The grey shaded areas in the left column indicate when there was a chamber cleaning followed by a dark $\mathrm{NO}_{3}+$ isoprene experiment that is not discussed here. By systematically scanning $\mathrm{H}_{2} \mathrm{O}_{2}$ and $\mathrm{NO}$ concentrations independently, we were able to test the response and composition of SOA across a range of oxidant conditions, ranging from more pristine to polluted in terms of $\mathrm{NO}_{x}$ concentrations.

All AMS and particle-phase FIGAERO-CIMS data were multiplied by a factor of 1.5 to correct for particle wall losses as described in Liu et al. (2016). We also describe the effect of seed particle surface area concentrations on SOA mass yields from this system in order to assess indirectly the role of vapor wall loss. The effect of added seed was minimal and as such data shown here were not corrected for vapor wall losses. Operating the chamber in continuous-flow mode possibly reduces the net flux of organic compounds to the walls, at least for low-volatility to semivolatile compounds, as some degree of equilibration can occur (Liu et al., 2016; Shilling et al., 2008). Nonetheless, our vapor concentration data may be biased low due to some amount of loss to the walls.

\section{Results and discussion}

\subsection{Effect of $\mathrm{NO}_{x}$ on major gas- and particle-phase species}

The gas- (Krechmer et al., 2015) and particle-phase (Liu et al., 2016; Riva et al., 2016) species detected from isoprene photochemical oxidation when examining the non-IEPOX SOA pathway were discussed previously. These studies identified several $\mathrm{C}_{5} \mathrm{H}_{8-12} \mathrm{O}_{4-8}$ compounds, among many others, and the findings presented here are broadly consistent. Figure 2 summarizes all compounds measured as an iodideadduct in both the gas (top) and particle (bottom) phases at both low (left) and high (right) input NO (20 ppb) for average spectra at steady state. The square root of the background subtracted signals was taken to show the dynamic range and was then normalized to the maximum signal within each individual plot. Green bars represent organic compounds with the formula $\mathrm{C}_{x} \mathrm{H}_{y} \mathrm{O}_{z} \mathrm{I}-$, while blue are organic nitrates $(\mathrm{OrgN})$ with the formula $\mathrm{C}_{x} \mathrm{H}_{y} \mathrm{NO}_{z} \mathrm{I}-$. It is possible 

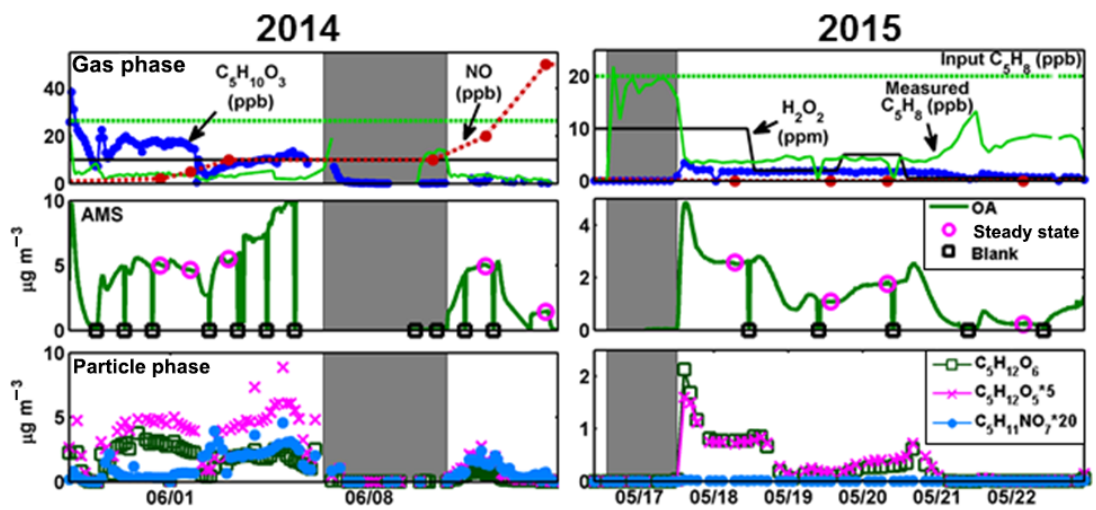

Figure 1. Overview of the 2014 and 2015 measurements taken at the PNNL. The left column is data from the 2014 campaign, and the right column is 2015. The top row shows gas-phase compounds measured by the PTR-MS and FIGAERO-CIMS as well as input concentrations of $\mathrm{H}_{2} \mathrm{O}_{2}$, NO, and isoprene. Middle row shows the OA as measured by the AMS. Steady-state periods are shown within magenta circles, AMS blanks as black squares. Select particle-phase species measured by the FIGAERO-CIMS are in the bottom row. Grey shaded areas in each column indicate when chamber lights were off for chamber cleaning and a dark $\mathrm{NO}_{3}$ experiment (in 2014) that is not discussed here. Note that the axis limits are not the same due to a wide range in concentrations across years, while $\mathrm{C}_{5} \mathrm{H}_{12} \mathrm{O}_{5}$ has been enhanced $5 \times$ and $\mathrm{C}_{5} \mathrm{H}_{11} \mathrm{NO}_{7}$ has been enhanced $20 \times$ in the bottom rows to clearly show the behavior of each species on the same axis.
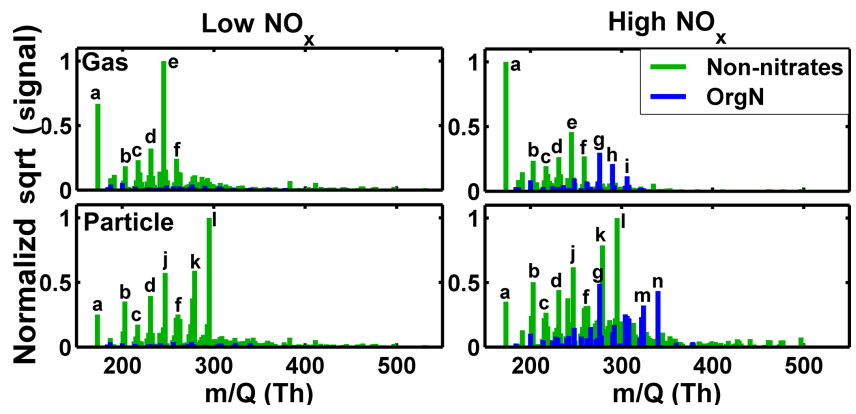

Figure 2. Mass spectra for compounds with the compositions $\mathrm{C}_{x} \mathrm{H}_{y} \mathrm{O}_{z} \mathrm{I}-$ (green) and $\mathrm{C}_{x} \mathrm{H}_{y} \mathrm{NO}_{z} \mathrm{I}-$ (blue) at low- (left) and high(right) NO input in both the gas (top) and particle (bottom) phases. Bars are sized by the square root of signal (counts $\mathrm{s}^{-1}$ for the gas phase, counts for the particle phase) to show the dynamic range. Major components are labeled with letters corresponding to those found in Table 1.

that dinitrates were measured, but due to their occurrence at masses where non-nitrates would be observed, they are difficult to conclusively identify and are thus not presented here. Major peaks are labeled with letters corresponding to compounds in Table 1. It is important to note that while the same molecular composition may be present in both the gas and particle phases, we do not suggest that they all exist as the same structure in each phase, although some likely do. We will discuss this further in later sections.

From Fig. 2, the two largest signals detected by the FIGAERO-CIMS in the gas phase at both low and high input $\mathrm{NO}$ are $\mathrm{CH}_{2} \mathrm{O}_{2}$ (presumably formic acid) and $\mathrm{C}_{5} \mathrm{H}_{10} \mathrm{O}_{3}$ (presumably the sum of IEPOX and ISOPOOH). With the addition of $\mathrm{NO}$, the $\mathrm{CH}_{2} \mathrm{O}_{2}$ signal becomes noticeably larger than that of $\mathrm{C}_{5} \mathrm{H}_{10} \mathrm{O}_{3}$, likely due to increased fragmentation.
Even without adding NO to the chamber there is still a small amount of $\mathrm{NO}_{x}$ present, likely from photolysis of inorganic nitrate on the chamber walls, as we measure non-negligible OrgN concentrations, even though the signal is very small relative to organics. The amount of $\mathrm{OrgN}$ in the gas phase increases with increased NO addition as expected. The majority of the OrgN compounds have five or fewer carbons and no one component dominates the OrgN. Notable signals include for example $\mathrm{C}_{4} \mathrm{H}_{7} \mathrm{NO}_{5}$ and $\mathrm{C}_{5} \mathrm{H}_{9} \mathrm{NO}_{5-6}$. The two largest signals detected by the FIGAERO-CIMS in the particle phase at both low and high input $\mathrm{NO}$ are $\mathrm{C}_{5} \mathrm{H}_{12} \mathrm{O}_{6}$ and $\mathrm{C}_{5} \mathrm{H}_{12} \mathrm{O}_{5}$. Other compounds, such as $\mathrm{C}_{5} \mathrm{H}_{10} \mathrm{O}_{4-7}$, with the isoprene $\mathrm{C}_{5}$ backbone but one degree of unsaturation also represent some of the largest signals at low $\mathrm{NO}_{x}$. As in the gas phase, no one component dominates the particle-phase $\operatorname{OrgN}$, although one of the strongest signals is $\mathrm{C}_{5} \mathrm{H}_{11} \mathrm{NO}_{7}$, the nitrate analogue to $\mathrm{C}_{5} \mathrm{H}_{12} \mathrm{O}_{6}$, formed from the same $\mathrm{C}_{5} \mathrm{H}_{11} \mathrm{O}_{6}$ peroxy radical (see Scheme 1). Compounds with the formula $\mathrm{C}_{5} \mathrm{H}_{7,9,11} \mathrm{NO}_{4-8}$ are all observed in the particle phase, consistent with field observations from an isoprene-emitting forest during the Southern Oxidant and Aerosol Study campaign (Lee et al., 2016). For compounds that are detected in the particle phase, their $T_{\max }$ and thermogram shape are also listed in Table 1 and lend information on the nature of these compounds, which will be discussed in further detail later on.

The general effect of $\mathrm{NO}_{x}$ on the SOA in this system has been described previously (Liu et al., 2016). Here we highlight the effect of input-NO concentrations on individual compounds by focusing on three of the most prominent particle-phase species (Fig. 3, top). As the inputNO concentration increases, $\mathrm{C}_{5} \mathrm{H}_{12} \mathrm{O}_{6}$ and $\mathrm{C}_{5} \mathrm{H}_{12} \mathrm{O}_{5}$ decrease nonlinearly. $\mathrm{C}_{5} \mathrm{H}_{11} \mathrm{NO}_{7}$, presumably produced from the ISOPOOH $+\mathrm{OH} \mathrm{C} \mathrm{C}_{5} \mathrm{H}_{11} \mathrm{O}_{6}$ peroxy radical, increases ini- 
Table 1. Gas- and particle-phase compounds detailed in the mass spectra in Fig. 2 (top). Many molecular compositions are observed in both the gas and particle phases. If the composition is observed in the particle phase, a $T_{\text {max }}$ is listed at both low ( 0 ppb input NO) and high ( 20 ppb input NO) $\mathrm{NO}_{x}$. The desorption shape is also listed and is consistent across $\mathrm{NO}_{x}$ conditions. The significance of the $T_{\max }$ and desorption shape are discussed in detail in the text. If the compound is only detected in the gas phase, "NA" is listed in the $T_{\max }$ and thermogram columns, indicating that those values are not applicable.

\begin{tabular}{|c|c|c|c|c|c|}
\hline Letter & Mass & $\begin{array}{l}\text { Molecular } \\
\text { composition }\end{array}$ & $\begin{array}{l}\text { Particle-phase } \\
T_{\max }, \text { low } \mathrm{NO}_{x}\end{array}$ & $\begin{array}{r}\text { Particle-phase } \\
T_{\max }, \text { high } \mathrm{NO}_{x}\end{array}$ & $\begin{array}{l}\text { Thermogram } \\
\text { shape }\end{array}$ \\
\hline $\mathrm{a}$ & 172.9105 & $\mathrm{CH}_{2} \mathrm{O}_{2} \mathrm{I}-$ & 87 & 94 & broad \\
\hline $\mathrm{b}$ & 202.9211 & $\mathrm{C}_{2} \mathrm{H}_{4} \mathrm{O}_{3} \mathrm{I}-$ & 113 & 115 & broad \\
\hline $\mathrm{c}$ & 216.9367 & $\mathrm{C}_{3} \mathrm{H}_{6} \mathrm{O}_{3} \mathrm{I}-$ & 76 & 100 & broad \\
\hline $\mathrm{d}$ & 230.9524 & $\mathrm{C}_{4} \mathrm{H}_{8} \mathrm{O}_{3} \mathrm{I}-$ & 87 & 115 & broad \\
\hline $\mathrm{e}$ & 244.968 & $\mathrm{C}_{5} \mathrm{H}_{10} \mathrm{O}_{3} \mathrm{I}-$ & NA & NA & NA \\
\hline $\mathrm{f}$ & 258.9473 & $\mathrm{C}_{5} \mathrm{H}_{8} \mathrm{O}_{4} \mathrm{I}-$ & 76,111 & 70,115 & double \\
\hline g & 275.9374 & $\mathrm{C}_{4} \mathrm{H}_{7} \mathrm{NO}_{5} \mathrm{I}-$ & 88 & 115 & broad \\
\hline $\mathrm{h}$ & 289.9531 & $\mathrm{C}_{5} \mathrm{H}_{9} \mathrm{NO}_{5} \mathrm{I}-$ & NA & NA & NA \\
\hline $\mathrm{i}$ & 305.948 & $\mathrm{C}_{5} \mathrm{H}_{9} \mathrm{NO}_{6} \mathrm{I}-$ & NA & NA & NA \\
\hline j & 246.9473 & $\mathrm{C}_{4} \mathrm{H}_{8} \mathrm{O}_{4} \mathrm{I}-$ & 95 & 110 & broad \\
\hline $\mathrm{k}$ & 278.9735 & $\mathrm{C}_{5} \mathrm{H}_{12} \mathrm{O}_{5} \mathrm{I}-$ & 60 & 48 & Gaussian \\
\hline 1 & 294.9684 & $\mathrm{C}_{5} \mathrm{H}_{12} \mathrm{O}_{6} \mathrm{I}-$ & 63 & 56 & Gaussian \\
\hline $\mathrm{m}$ & 323.9586 & $\mathrm{C}_{5} \mathrm{H}_{11} \mathrm{NO}_{7} \mathrm{I}-$ & 72 & 50 & Gaussian \\
\hline $\mathrm{n}$ & 339.9535 & $\mathrm{C}_{5} \mathrm{H}_{11} \mathrm{NO}_{8} \mathrm{I}-$ & 53 & 45 & Gaussian \\
\hline
\end{tabular}

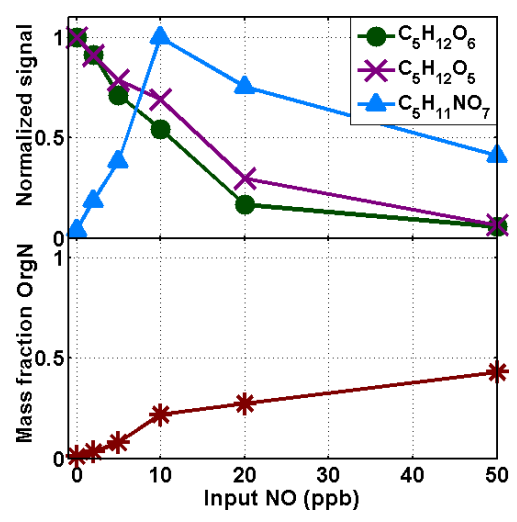

Figure 3. Top: normalized signals of $\mathrm{C}_{5} \mathrm{H}_{12} \mathrm{O}_{6}$ and $\mathrm{C}_{5} \mathrm{H}_{11} \mathrm{NO}_{7}$, believed to originate in the gas phase from the same $\mathrm{C}_{5} \mathrm{H}_{11} \mathrm{O}_{6}$ peroxy radical and $\mathrm{C}_{5} \mathrm{H}_{12} \mathrm{O}_{5}$, as a function of input NO. Signal is normalized to maximum signal for each compound to show the relative behaviors. Bottom: the mass fraction of organic nitrates as a function of NO. Mass fraction refers to the mass concentration of FIGAERO-CIMS-measured OrgN relative to the total mass concentration of organics (non-nitrogen containing $+\operatorname{OrgN}$ ) measured by the FIGAERO-CIMS.

tially with increasing $\mathrm{NO}$ addition. Above moderate NO input (>10 ppb), $\mathrm{C}_{5} \mathrm{H}_{11} \mathrm{NO}_{7}$, a nitrate, begins to decrease with further increases in $\mathrm{NO}$ addition, likely a result of ISOPOOH also decreasing as the $\mathrm{C}_{5} \mathrm{H}_{9} \mathrm{O}_{3}$ peroxy radical reacts more with $\mathrm{NO}$ as opposed to $\mathrm{HO}_{2}$. This behavior supports previous observations of low-isoprene SOA yields at high $\mathrm{NO}_{x}$ (Kroll et al., 2005, 2006; Lane et al., 2008; Xu et al., 2014; Zhang et al., 2011), though we note a monotonic $\mathrm{NO}_{x}$ dependence of SOA yield in our experiments (Liu et al., 2016).
The bottom panel of Fig. 3 depicts the mass fraction of OrgN as a function of input NO. The mass fraction of OrgN increases rapidly between 0 and $10 \mathrm{ppb} \mathrm{NO}$ input and more modestly above that. At the highest input NO concentration, OrgN make up $\sim 40 \%$ of the organic aerosol mass detected by the FIGAERO-CIMS. This estimate carries uncertainty due to the inability to calibrate to every OrgN compound, as well as a lack of a single dominant OrgN. At the highest input $\mathrm{NO}$, the AMS measurements also indicate that OrgN make up $\sim 40 \%$ of the SOA mass, assuming a molecular weight of the typical OrgN of $148 \mathrm{~g} \mathrm{~mol}^{-1}$ based on the measured FIGAERO-CIMS particle-phase OrgN distribution, which is consistent with our findings. Though considerable uncertainties exist with respect to quantification of OrgN using both the AMS and the FIGAERO-CIMS, the agreement between these independent measurements suggests that the calibration factors applied to the FIGAERO-CIMS OrgN signals are reasonable. We draw two main conclusions from this analysis: (1) the complementary increase in OrgN and decrease in non-nitrates likely accounts for the stable SOA mass yields at lower input NO concentrations as reported previously (Liu et al., 2016), with the highest input NO concentrations resulting in a decrease in both OrgN and non-nitrates, corresponding to the sharp decrease in SOA mass yield at the highest input NO concentration ( $50 \mathrm{ppb}$ ) and (2) while there is no one OrgN that is most prominent in the gas or particle phases, the total OrgN can comprise up to $40 \%$ of the SOA mass at high input NO concentrations (50 ppb). 

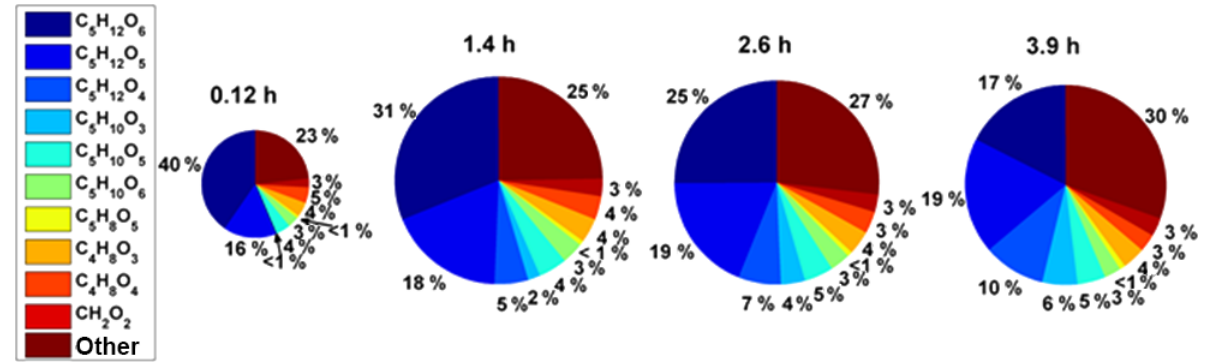

Figure 4. Time evolution of particle-phase concentrations in a batch mode isoprene photochemical oxidation experiment at low $\mathrm{NO}_{x}$. Time increases from left to right and the size of the pies is proportional to the amount of OA present, which is $5.6,10.8,10.6$, and $10.4 \mu \mathrm{g} \mathrm{m}^{-3}$ from left to right.

\subsection{Time evolution of low-NO $x$ isoprene SOA composition}

To examine how isoprene photochemical SOA evolves over time, a time-dependent experiment was conducted (Fig. 4), similar to a previous batch mode study (Kroll et al., 2006). In this "batch mode" experiment, isoprene, $\mathrm{H}_{2} \mathrm{O}_{2}$, and solid ammonium sulfate seed were injected into the chamber, and then the lights were turned on. The chemistry of the closed system was allowed to evolve in time without further input of reactants. Each pie chart represents a FIGAERO-CIMS particle-phase desorption measurement over the course of the experiment. The data are converted to mass concentration as discussed previously (Lee et al., 2016; Liu et al., 2016), the overall size of each pie chart is proportional to the amount of AMS-measured OA $\left(5.6,10.8,10.6,10.4 \mathrm{\mu g} \mathrm{m}^{-3}\right.$ from left to right, corrected for particle wall loss), and the time is the mid-point of the particle collection period (which lasted $25 \mathrm{~min}$ ) relative to the initiation of the chemistry. The desorption just prior to the isoprene injection is used as the baseline, and the corresponding mass spectra are subtracted from the succeeding desorption. Unlike the work of Kroll et al. (2006), who saw SOA volume maximize after $\sim 3-4 \mathrm{~h}$ of oxidation followed by a large decrease in total volume attributed to photochemical processing, the measurements presented here did not follow the reaction progress long after the maximum OA concentration was achieved $(<1 \mathrm{~h})$ and thus we did not observe a significant decrease in mass.

The absolute and relative concentration of $\mathrm{C}_{5} \mathrm{H}_{12} \mathrm{O}_{6}$ in the particle phase decreases from $40 \%$ of the particle-phase SOA to $17 \%$ over the $4 \mathrm{~h}$ of oxidation. The absolute mass of SOA also changes, primarily increasing, during the experiment, reaching a peak of $11.6 \mu \mathrm{g} \mathrm{m}^{-3}$ at $t=4.3 \mathrm{~h}$. This suggests that $\mathrm{C}_{5} \mathrm{H}_{12} \mathrm{O}_{6}$ is transforming either within the particle phase via hydrolysis or other mechanisms, or in the gas phase, with efficient gas-particle equilibration due to reaction with $\mathrm{OH}$ or photolysis (Baasandorj et al., 2010; Hsieh et al., 2014; Roehl et al., 2007), with a particle-phase halflife of $\sim 4 \mathrm{~h}$. Gas-phase oxidation seems unlikely given that typically greater than $95 \%$ of the $\mathrm{C}_{5} \mathrm{H}_{12} \mathrm{O}_{6}$ is found in the particle phase (Fig. 5) when OA $>2 \mu \mathrm{g} \mathrm{m}^{-3}$. While many of the detected compounds are present at constant mass fractions throughout time, $\mathrm{C}_{5} \mathrm{H}_{12} \mathrm{O}_{5}, \mathrm{C}_{5} \mathrm{H}_{12} \mathrm{O}_{4}$, and $\mathrm{C}_{5} \mathrm{H}_{10} \mathrm{O}_{3}$ increase. $\mathrm{C}_{5} \mathrm{H}_{12} \mathrm{O}_{5}$ has been observed previously in the gas phase from ISOPOOH oxidation (Krechmer et al., 2015), and was also shown to be a large fraction of the particle phase from isoprene oxidation (Liu et al., 2016), but its production mechanism is uncertain. Krechmer et al. (2015) suggest it could be formed from the oxidation of an impurity in the ISOPOOH, although the experiments presented here use isoprene as the BVOC precursor, ruling out this explanation. In these experiments, $\mathrm{C}_{5} \mathrm{H}_{12} \mathrm{O}_{5}$ is observed within the first hour of isoprene oxidation and increases to $\sim 18 \%$ of the OA mass within $1.5 \mathrm{~h}$, becoming relatively stable thereafter. Two possible sources of this compound are the reaction of the ISOPOOH-derived peroxy radical $\left(\mathrm{C}_{5} \mathrm{H}_{11} \mathrm{O}_{6}\right)$ with $\mathrm{RO}_{2}$, or a dihydroxy alkene undergoing reaction with $\mathrm{OH}$ and $\mathrm{O}_{2}$ to form a dihydroxy peroxy radical, followed by reaction with $\mathrm{HO}_{2}$. It is also possible that $\mathrm{C}_{5} \mathrm{H}_{12} \mathrm{O}_{5}$ could be formed in the condensed phase from hydrolysis reactions. Further work is required to understand the source of this compound.

The other two compounds that increase with time, $\mathrm{C}_{5} \mathrm{H}_{12} \mathrm{O}_{4}$ and $\mathrm{C}_{5} \mathrm{H}_{10} \mathrm{O}_{3}$, likely isomers of 2-methyl tetrols and alkene triols, respectively, are traditional markers of IEPOX-derived SOA (Claeys et al., 2004; Ding et al., 2008; Edney et al., 2005; Kourtchev et al., 2005; Surratt et al., 2010; Xia and Hopke, 2006). This result is unexpected given that using effloresced (solid) ammonium sulfate seed at a $\mathrm{RH}$ below the deliquescence point $(\mathrm{RH} \sim 50 \%)$ together with an SOA coating should strongly suppress the known acid-catalyzed IEPOX multiphase chemistry (Gaston et al., 2014; Lin et al., 2012, 2013a, b, 2014; Liu et al., 2014; Nguyen et al., 2014; Paulot et al., 2009b; Surratt et al., 2006, 2010). We tested the uptake of an authentic IEPOX standard onto dry, crystalline ammonium sulfate seed under conditions similar to these, during continuous-flow mode though, and found no measurable uptake and SOA formation (Liu et al., 2016). However, it is consistent with previous work that found both of these tracers in SOA when isoprene was oxidized in the absence of deliquesced acidic seed 


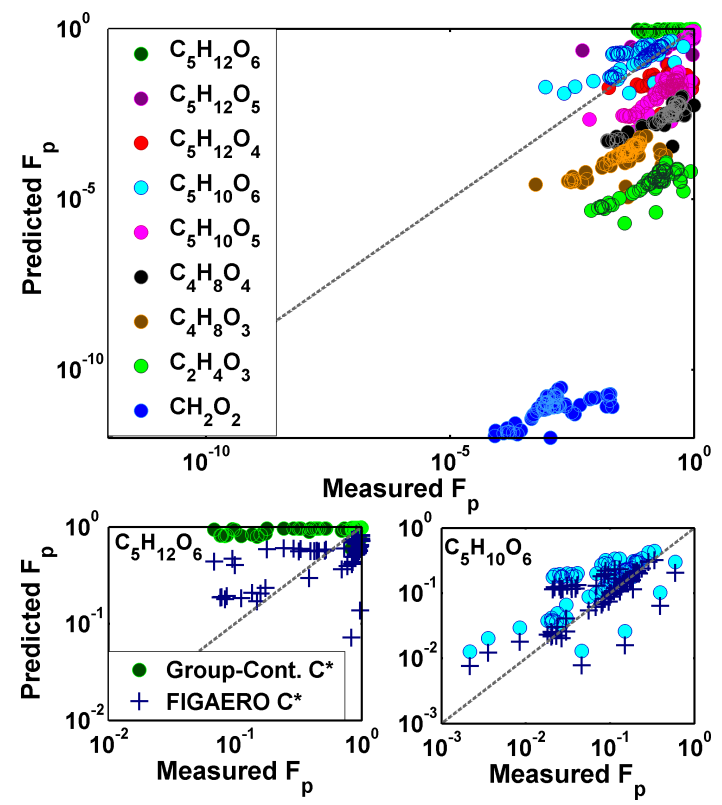

Figure 5. Top: predicted versus measured fraction in the particle phase $\left(F_{\mathrm{p}}\right)$. Predicted $F_{\mathrm{p}}$ is obtained from Eq. (1) where $C^{*}$ s were calculated with the EVAPORATION group-contribution method (Compernolle et al., 2011) labeled as "Group-Cont. $C^{*}$ " in the bottom panels. Measured $F_{\mathrm{p}}$ is the direct measurement from the FIGAERO. Bottom: the $F_{\mathrm{p}}$ can also be predicted based on the calibrated FIGAERO temperature axis as discussed in the methods and is shown as the predicted $F_{\mathrm{p}}$ here. Agreement can be reached for two representative compounds where the $F_{\mathrm{p}}$ is over and correctly predicted (left and right, respectively).

(Edney et al., 2005; Kleindienst et al., 2009). $\mathrm{C}_{5} \mathrm{H}_{12} \mathrm{O}_{4}$ and $\mathrm{C}_{5} \mathrm{H}_{10} \mathrm{O}_{3}$ are less than $1 \%$ of the SOA for the first $2 \mathrm{~h}$ and then gradually increase to 10 and $6 \%$ of the SOA, respectively, after $4 \mathrm{~h}$. Interestingly, the FIGAERO-CIMS thermograms for these tracers have broad maxima at much higher $T_{\max }$ than would be consistent with their elemental composition. Lopez-Hilfiker et al. (2016b) noted two modes in the thermogram of $\mathrm{C}_{5} \mathrm{H}_{12} \mathrm{O}_{4}$, one with a $T_{\max }$ as expected based on its structure and another with a higher $T_{\max }$ indicating an effectively lower-volatility component thermally decomposing. These two tracers are also observed in the $\mathrm{NO}_{x}$-addition experiments performed in continuous-flow mode, though at lower concentrations. In these experiments there was not enough NO to completely suppress ISOPOOH formation and therefore IEPOX formation from ISOPOOH $+\mathrm{OH}$. Moreover, IEPOX can also form, albeit at lower yields, from $\mathrm{OH}$ reactions with the first-generation isoprene hydroxy nitrate (Jacobs et al., 2014; L. Lee et al., 2014; St. Clair et al., 2016). However, the formation of IEPOX SOA tracers is more puzzling given the very low reactive uptake of IEPOX expected on solid inorganic seed coated with isoprene SOA (Gaston et al., 2014; Riedel et al., 2015). Perhaps nitric-acid-catalyzed IEPOX multiphase chemistry contributes to the formation of these tracers at high $\mathrm{NO}_{x}$. That said, observation of these tracers, also in the absence of $\mathrm{NO}_{x}$ addition, indicates that this explanation is not sufficient.

The chemical mechanism leading to the measurement of these tracers in the particle phase is unknown, but given that the experimental conditions strongly suppressed the traditional acid-catalyzed aqueous IEPOX chemistry, perhaps these tracers are not solely derived from aqueous IEPOX chemistry but isoprene photochemical oxidation more generally. In conclusion, $\mathrm{C}_{5} \mathrm{H}_{12} \mathrm{O}_{6}$ condenses rapidly and initially and makes up the majority of the SOA mass, but over time its contribution decreases as other compounds such as $\mathrm{C}_{5} \mathrm{H}_{12} \mathrm{O}_{5}, \mathrm{C}_{5} \mathrm{H}_{12} \mathrm{O}_{4}$, and $\mathrm{C}_{5} \mathrm{H}_{10} \mathrm{O}_{3}$ increase. Our data suggest these compounds may be formed in the particle phase from heterogeneous reactions and/or during the thermal desorption analysis, but more work is required to determine their sources.

\subsection{Gas-particle partitioning: saturation vapor concentrations and oligomeric content}

The volatility of the products generated from the non-IEPOX $\mathrm{C}_{5} \mathrm{H}_{12} \mathrm{O}_{6}$ pathway (Krechmer et al., 2015; Liu et al., 2016; Riva et al., 2016) will be a crucial aspect of its contribution to SOA formation and the lifetime of the resulting SOA against dilution, gas-phase oxidation, and depositional losses. The capability of the FIGAERO-CIMS to measure the concentration of individual species in both the gas and particle phases allows for a direct measurement of the particle-phase fraction $\left(F_{\mathrm{p}}\right)$, which is the particle-phase concentration relative to the gas- and particle-phase concentrations per volume of air. The $F_{\mathrm{p}}$ can also be calculated from an assumption of equilibrium absorptive partitioning theory first described by Pankow (1994) using Eq. (1) as first reported by Donahue et al. (2006), where $C^{*}$ is the saturation vapor concentration $\left(\mu \mathrm{g} \mathrm{m}^{-3}\right)$ of the pure substance and $C_{\mathrm{OA}}$ is the concentration of organic aerosol $\left(\mu \mathrm{g} \mathrm{m}^{-3}\right)$.

$F_{\mathrm{p}}=\left(1+\frac{C^{*}}{C_{\mathrm{OA}}}\right)^{-1}$

Equation (1) neglects the activity coefficient and molecular weight differences for simplicity, though any $C^{*}$ derived from a comparison to Eq. (1) would implicitly include these factors. Calibration standards do not exist for the vast majority of compounds in SOA and therefore the $C^{*}$ is largely unknown, somewhat mitigating the impact of such simplifications. Group-contribution methods exist to estimate $C^{*}$, where each functional group represents a discrete, empirically determined contribution to the equilibrium vapor pressure of a compound (Capouet and Muller, 2006; Compernolle et al., 2011; Nannoolal et al., 2008; Pankow and Asher, 2008). These approaches carry substantial uncertainty for atmospheric SOA systems, in large part due to the lack of enough standards to develop a robust parameterization. In addition, these approaches do not directly address the potential 
of functional group interactions, such as intramolecular hydrogen bonding, which can lead to $C^{*}$ estimates that are significantly biased low when not included (Kurten et al., 2016).

Measured $F_{\mathrm{p}}$ were determined using the FIGAERO-CIMS for a subset of major particle-phase components from 2015 (Fig. 5). A short (1-2 m) laminar flow Teflon inlet line with a short residence time $(<1 \mathrm{~s})$ was coupled to the chamber for the detection of gases by the FIGAERO-CIMS. The largest source of error in the measured $F_{\mathrm{p}}$, beyond thermal decomposition during desorption, is diffusion-controlled vapor losses in the inlet, which were corrected for by assuming a diffusivity of $0.05-0.1 \mathrm{~cm}^{2} \mathrm{~s}^{-1}$, although the variability is not discernable on the log scale. Inlet losses are $25-44 \%$ for the range of diffusivities, a small effect on the comparison of measured and predicted $F_{\mathrm{p}}$ as we show below.

$F_{\mathrm{p}}$ were predicted using Eq. (1) with $C_{\mathrm{OA}}$ measured by the AMS and $C^{*}$ calculated via the EVAPORATION groupcontribution method (Compernolle et al., 2011), which generally gave similar estimates as the Capouet and Muller approach (2006). The Nannoolal method (2008) was also explored, but it gave $C^{*}$ estimates that varied by several orders of magnitude for structurally similar compounds, as well as estimates that were unexpectedly low based on FIGAERO-CIMS measurements and what one would expect based on molecular structure, consistent with previous findings (Kurten et al., 2016). The SIMPOL method of Pankow and Asher (2008) was also applied to select compounds and is discussed below. A major limitation of this analysis is that we do not know the structure of the molecules detected, only the elemental composition, and so we make assumptions based on the most likely functional groups expected from the chemical conditions of the chamber and from the elemental composition (e.g., degrees of unsaturation, oxygento-carbon ratio). In many cases these assumptions have little impact on our conclusions since the inferred errors are far larger than expected from possible isomers.

If the SOA formed according to equilibrium partitioning theory as first described by Pankow (1994), the $F_{\mathrm{p}}$ measured by the FIGAERO-CIMS and the $C^{*}$ calculated using group-contribution methods should be in agreement over a range of organic aerosol mass concentrations. Figure 5 indicates two immediate challenges in testing partitioning theory. First, a large number of mostly small carbon number compounds have a much higher measured $F_{\mathrm{p}}$ relative to the predicted $F_{\mathrm{p}}$ based on their group-contribution-determined $C^{*}$. The $C^{*}$ estimates would have to be in error by 5 or more orders of magnitude, which is likely not the case since there are many measurements of vapor pressures for similar compounds. Furthermore, the thermograms of these compounds appear broad, not Gaussian as expected for individual non-interacting compounds (Lopez-Hilfiker et al., 2014), and they do not peak until $\sim 85^{\circ} \mathrm{C}$ or higher, see Table 1 , which is also inconsistent with the calibrated composition and enthalpy of sublimation relationship scaled for the FIGAERO used here (Lopez-Hilfiker et al., 2014). We attribute this behavior to thermal decomposition of lower-volatility components during the desorption process giving rise to smaller molecular weight, more volatile components as in previous studies of IEPOX SOA tracers in the southeastern US (Lopez-Hilfiker et al., 2016b), $\alpha$-pinene-derived chamber SOA (Lopez-Hilfiker et al., 2015), and biomass burning organic aerosol in the northwestern US (Gaston et al., 2016). That is, the disagreement between measured and predicted $F_{\mathrm{p}}$ for these compounds is not necessarily a failure of equilibrium partitioning theory, nor evidence that equilibrium had not been achieved, but rather that the compounds desorbing were actually part of another larger molecular weight oligomerization product, the $C^{*}$ and gas-phase concentrations of which are unknown.

The second challenge to testing gas-particle partitioning is illustrated in the $F_{\mathrm{p}}$ for two representative compounds, $\mathrm{C}_{5} \mathrm{H}_{12} \mathrm{O}_{6}$ and $\mathrm{C}_{5} \mathrm{H}_{10} \mathrm{O}_{6}$ (Fig. 5, bottom panels). That there is reasonable agreement between measured and predicted $F_{\mathrm{p}}$ (Fig. 5, bottom right, circles) for $\mathrm{C}_{5} \mathrm{H}_{10} \mathrm{O}_{6}$ suggests that equilibrium partitioning is potentially achieved in the chamber. However, the disagreement for $\mathrm{C}_{5} \mathrm{H}_{12} \mathrm{O}_{6}$ (Fig. 5, bottom left, circles) cannot be explained solely by thermal decomposition of lower-volatility material for two reasons: the thermogram shape is nearly Gaussian and therefore behaves like a single component and the predicted $F_{\mathrm{p}}$ is much larger than measured (opposite to the situation above). This behavior implies inaccurate $C^{*}$ derived from the group-contribution methods as opposed to thermal decomposition.

The EVAPORATION group-contribution method (Compernolle et al., 2011) used in Fig. 5 and that of Capouet and Muller (2006) both produce a $C^{*}$ of $0.03 \mu \mathrm{g} \mathrm{m}^{-3}$ for $\mathrm{C}_{5} \mathrm{H}_{12} \mathrm{O}_{6}$ when assuming it is a dihydroxy dihydroperoxide, while the SIMPOL method predicts $2 \mu \mathrm{g} \mathrm{m}^{-3}$ (Pankow and Asher, 2008). For $\mathrm{C}_{5} \mathrm{H}_{10} \mathrm{O}_{6}$, assumed to be a hydroxy dihydroperoxy aldehyde, EVAPORATION (Compernolle et al., 2011) predicts $4 \mu \mathrm{g} \mathrm{m}^{-3}$, the Capouet and Muller (2006) method predicts $2 \mu \mathrm{g} \mathrm{m}^{-3}$, and SIMPOL (Pankow and Asher, 2008) suggests $20 \mu \mathrm{g} \mathrm{m}^{-3}$. That the $\mathrm{C}_{5} \mathrm{H}_{12} \mathrm{O}_{6}$ values vary by 2 orders of magnitude while the $\mathrm{C}_{5} \mathrm{H}_{10} \mathrm{O}_{6}$ values vary by a factor of 10 suggests the need for better experimental constraints. Using the measured $T_{\max }$ from the FIGAEROCIMS thermograms, the $C^{*}$ of $\mathrm{C}_{5} \mathrm{H}_{12} \mathrm{O}_{6}$ and $\mathrm{C}_{5} \mathrm{H}_{10} \mathrm{O}_{6}$ were determined to be 0.7 and $7 \mu \mathrm{g} \mathrm{m}^{-3}$, respectively. These values were then used to re-calculate the predicted $F_{\mathrm{p}}$ using Eq. (1). The original group-contribution-calculated $F_{\mathrm{p}}$ is shown alongside the adjusted points in the bottom panels of Fig. 5 as navy crosses. The root mean square error of both $\mathrm{C}_{5} \mathrm{H}_{12} \mathrm{O}_{6}$ and $\mathrm{C}_{5} \mathrm{H}_{10} \mathrm{O}_{6}$ is minimized when comparing the measurements with the adjusted $F_{\mathrm{p}}$, indicating that the calibrated FIGAERO-CIMS temperature axis can more accurately determine the $C^{*}$.

There are a number of possible reasons why measured and predicted $F_{\mathrm{p}}$ do not agree, with one being that our methods to estimate $C^{*}$ are flawed. This potential source of error can be addressed directly with the FIGAERO-CIMS thermo- 
grams, independently of the measured $F_{\mathrm{p}}$, thereby allowing for a more robust assessment of whether (i) the assumption of gas-particle equilibrium is reasonable, (ii) there are possible biases in the measured $F_{\mathrm{p}}$ due to thermal decomposition, or (iii) the $C^{*}$ estimation methods are valid. The analysis above demonstrates that all possibilities arise in this data set.

In the case of $\mathrm{C}_{5} \mathrm{H}_{12} \mathrm{O}_{6}$ the FIGAERO-CIMS-determined $C^{*}$ is much closer to the SIMPOL estimation and significantly higher than that estimated by the other groupcontribution methods. We suspect the large differences between measured and group-contribution method estimates of $C^{*}$ in this case are due to the lack of vapor pressure data on compounds with hydroperoxide groups, specifically multifunctional hydroperoxides: there are only data on four hydroperoxide-containing compounds on which these methods are based (Capouet and Muller, 2006; Compernolle et al., 2011). It can be argued that $-\mathrm{OH}$ and $-\mathrm{OOH}$ groups will lower the $C^{*}$ relative to the precursor by a comparable amount, with the possibility that a - $\mathrm{OOH}$ group could lower it slightly more due to the additional oxygen. For example, the $C^{*}$ of 2-methyl-1,2,3,4-butanol $\left(\mathrm{C}_{5} \mathrm{H}_{12} \mathrm{O}_{4}\right)$ was calculated to be 9 to $34 \mu \mathrm{g} \mathrm{m}^{-3}$, depending on the method used (Capouet and Muller, 2006; Compernolle et al., 2011), which is roughly 250-1000 times greater than the $C^{*}$ estimates for $\mathrm{C}_{5} \mathrm{H}_{12} \mathrm{O}_{6}$. That is, a molecule with the same number of distinct -OH-containing functional groups is predicted to have a very different $C^{*}$ because the vapor pressure lowering of -OOH groups assumed by these group-contribution methods is larger than that for an -OH group. Our observations suggest that this assumption is incorrect, at least to the extent employed in these methods. This is supported by previous work that found that group-contribution methods predicted significantly lower $C^{*}$ than two computational models, the conductor-like screening model for real solvents (COSMORS) (Kurten et al., 2016) and the generator for explicit chemistry and kinetics of organics in the atmosphere (GECKO-A) (Valorso et al., 2011), did for compounds with multiple functionalities. Conversely, we assume $\mathrm{C}_{5} \mathrm{H}_{10} \mathrm{O}_{6}$ is a hydroxy dihydroperoxy aldehyde, also with two -OOH groups, but the group contribution methods accurately predicted a $C^{*}$ consistent with that inferred from the FIGAERO-CIMS $T_{\max }$. This agreement may be a coincidence or indicative of the fact that multifunctional compounds with slightly different functional groups can have significantly different intramolecular interactions, leading to significantly different saturation vapor concentrations (Compernolle et al., 2011).

Figure 5 leads to two main conclusions. The first is that testing equilibrium partitioning theory is a challenge without a direct constraint on the $C^{*}$ like the FIGAERO-CIMS desorption $T_{\max }$ due to possibly large systematic errors in the $C^{*}$ predicted from group-contribution methods. Moreover, thermal decomposition of higher molecular weight compounds, such as oligomers, into smaller molecular weight compounds generates uncertainty in the measured $F_{\mathrm{p}}$ in that the $C^{*}$ derived from FIGAERO-CIMS $T_{\max }$ does not correspond in
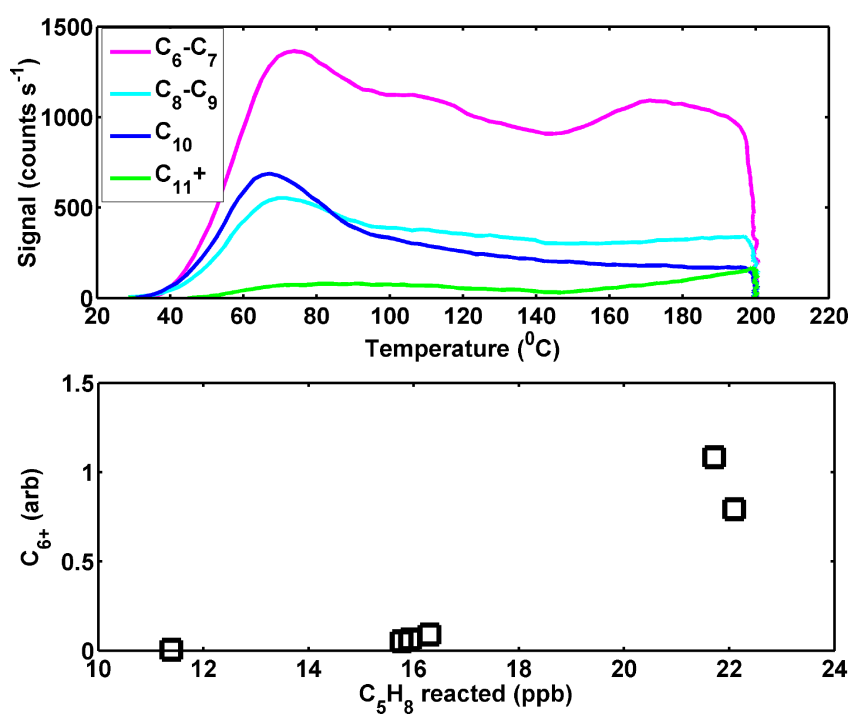

Figure 6. Top: sum of the thermogram signal for compounds with the formula $\mathrm{C}_{x} \mathrm{H}_{y} \mathrm{O}_{z} \mathrm{I}-$, where $x$ is varied across each thermogram and represents compounds with six or more carbons. Bottom: the sum off the mass concentration of all compounds with six or more carbons relative to the mass concentration of organic aerosol as a function of reacted isoprene.

such cases to the observed molecule. This result leads to our second conclusion: a surprisingly large fraction of the iSOA is resistant to evaporation, indicating it will have a longer lifetime against dilution (Kroll et al., 2006). Approximately $30-45 \%$ of the SOA mass detected by the FIGAEROCIMS desorbs at temperatures greater than $80^{\circ} \mathrm{C}$, much of that above $100^{\circ} \mathrm{C}$, which corresponds to effective enthalpies of sublimation $>150 \mathrm{~kJ} \mathrm{~mol}^{-1}$ in our FIGAERO-CIMS assuming no diffusion limitations on evaporation from the particles that exist at these temperatures (for example, due to highly viscous phases). We note that Kroll et al. (2006) also found evidence for a significant mass fraction of large molecular weight compounds when applying the AMS to low$\mathrm{NO}_{x}$ non-IEPOX iSOA. We conclude that oligomerization products are the cause of this more refractory SOA component, but we cannot determine from the thermograms alone whether the oligomerization process is reversible at ambient temperatures on longer timescales than the $\sim 1 \mathrm{~h}$ desorption. That the SOA yield from isoprene is significantly higher for similar organic mass loadings than that reported from ISOPOOH only suggests an important role for the broader distribution of oxidation products formed in addition to those from ISOPOOH. One possible reason is that these mostly semivolatile products can contribute to lower-volatility products via oligomerization chemistry (Jathar et al., 2016; Sato et al., 2011; Tsai et al., 2015).

The sum of thermogram signals across all ions with the formula $\mathrm{C}_{x} \mathrm{H}_{y} \mathrm{O}_{z} \mathrm{~N}_{0-1} \mathrm{I}-$ is presented in Fig. 6, with the value of $x$ specified for each thermogram. We measured non- 
negligible signal for compounds with six or more carbons, consistent with the possibility of oligomerization products. Such compounds account for $\sim 5-15 \%$ of detected mass. Compounds with six to seven carbons make up a majority of the signal for compounds with greater than five carbons, though we also detected significant signal in $\mathrm{C}_{8}-\mathrm{C}_{10}$ compounds, themselves making up 3-8\% of detected mass. We measure a monoterpene impurity at $0.3 \%$ of the isoprene concentration in our gas cylinder, which could result in $\sim 0.05-0.1 \mu \mathrm{g} \mathrm{m}^{-3}$ of monoterpene SOA, i.e., $0.3-2.8 \%$ of the SOA mass, which is significantly lower than the sum of all compounds with six or more carbons as well as the sum of just $\mathrm{C}_{8-10}$ compounds. Furthermore, the ratio of $\mathrm{C}_{6-7}$ to $\mathrm{C}_{10}$ compounds is 5-10 times higher than we detected in monoterpene $+\mathrm{OH}$ experiments performed in the same chamber with the same FIGAERO-CIMS. We also note that a previous study similar to the ones presented here detected $\mathrm{C}_{10} \mathrm{H}_{20-22} \mathrm{O}_{6-9}$ compounds, as well as a fragment ion in the AMS at $m / z 91$ corresponding to $\mathrm{C}_{7} \mathrm{H}_{7}+$, which was tentatively attributed to thermal decomposition of dimers and oligomers on the vaporizer, among other possibilities (Riva et al., 2016). The mass concentration of these compounds with six or more carbons was found to increase with reacted isoprene (Fig. 6, bottom). At the highest reacted isoprene, compounds with six or more carbons contribute on order $25 \%$ to the total OA mass detected.

\subsection{Role of $\mathrm{NO}_{x}$ in iSOA volatility}

Previous studies using thermal denuders and either an AMS or a tandem differential mobility measurement of particle size distributions have found that iSOA formed in the presence of $\mathrm{NO}_{x}$ is less volatile relative to that formed in $\mathrm{HO}_{2}$ dominant regimes (Kleindienst et al., 2009; Xu et al., 2014). We compare the iSOA volatility under different regimes by looking at the sum thermograms for compounds with the formula $\mathrm{C}_{x} \mathrm{H}_{y} \mathrm{O}_{z} \mathrm{~N}_{0-1} \mathrm{I}^{-}$. These sum thermograms are plotted as a function of temperature for both low- and high- $\mathrm{NO}_{x}$ conditions in Fig. 7, bottom left and right, respectively. Since $\mathrm{C}_{5} \mathrm{H}_{12} \mathrm{O}_{6}$ is a large portion of the SOA mass concentration in these experiments (e.g., Fig. 4), it is shown separately in dark green, with the remainder of the summed signal shown in light green. $\mathrm{C}_{5} \mathrm{H}_{12} \mathrm{O}_{6}$ is clearly a large contribution to the sum signal in both the low- and high- $\mathrm{NO}_{x}$ cases, although more so in the low- $\mathrm{NO}_{x}$ regime, with the remaining thermogram signal primarily located in the lower-volatility (higher temperature) "tail" of the desorption. We have also shown in the bottom left low- $\mathrm{NO}_{x}$ figure a sum of the thermograms for all compounds with six or more carbons, i.e., the sum of all thermograms in Fig. 6. We note that the sum of these compounds makes up $\sim 6 \%$ of the total signal. At high $\mathrm{NO}_{x}$, there are two clear modes remaining in the thermogram after removing the $\mathrm{C}_{5} \mathrm{H}_{12} \mathrm{O}_{6}$ contribution (light green): one mode at roughly the same $T_{\max }$, and therefore volatility, of $\mathrm{C}_{5} \mathrm{H}_{12} \mathrm{O}_{6}$, and the other mode at a higher $T_{\max }, \sim 110^{\circ} \mathrm{C}$,
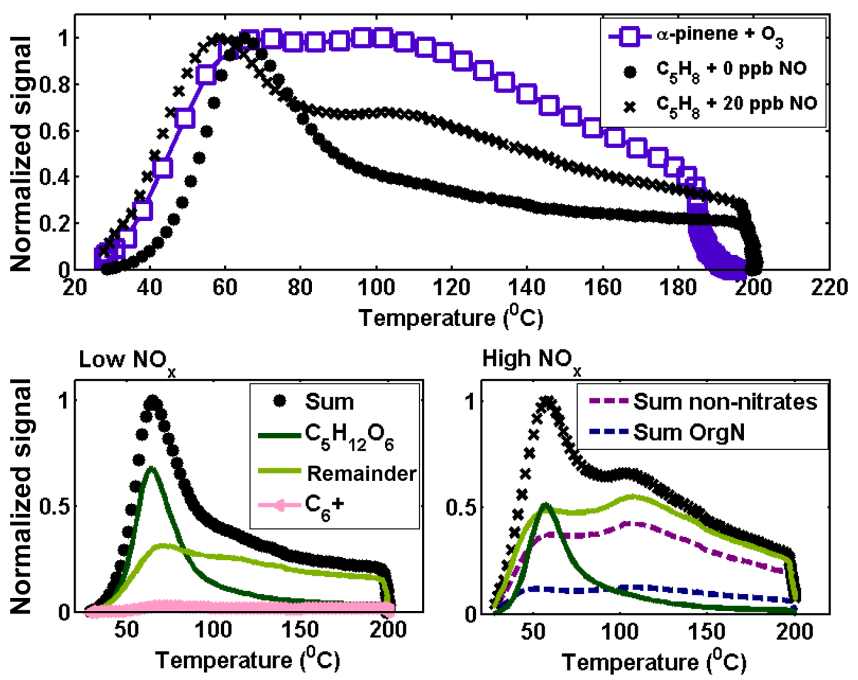

Figure 7. Top: sum thermograms of $\alpha$-pinene $+\mathrm{O}_{3}$ compared to isoprene $\left(\mathrm{C}_{5} \mathrm{H}_{8}\right)$ photooxidation with and without $\mathrm{NO}_{x}$. The $\alpha$ pinene sum thermogram was reported previously (Lopez-Hilfiker et al. (2015), Fig. 5). Bottom: the sum thermograms at low (left) and high (right) input NO. The thermogram of $\mathrm{C}_{5} \mathrm{H}_{12} \mathrm{O}_{6}$, the largest signal in both cases, is separated out (dark green) and the sum of the remaining signal minus $\mathrm{C}_{5} \mathrm{H}_{12} \mathrm{O}_{6}$ is displayed as the remaining signal (light green). At low-NO input, the sum of compounds with six or more carbons is specified (pink triangle and line), while at high-NO input the sum of OrgN and the sum of non-nitrate organics are plotted (dashed lines, independent of solid lines) to show the relative thermogram features.

suggesting that a larger fraction of detected iSOA mass at high $\mathrm{NO}_{x}$ is resistant to evaporation compared to the low$\mathrm{NO}_{x}$ case. We also note that the $T_{\max }$ of individual compounds shifts to higher values with the addition of $\mathrm{NO}_{x}$ except for the highest mass compounds (see Table 1). Although the thermograms for many of these compounds do not have a distinct Gaussian shape, making determination of the $T_{\max }$ uncertain or undefined, the shift to higher $T_{\max }$ for the same compounds could indicate not just lower-volatility products in the form of oligomers but also potentially a change in the overall particle viscosity, causing the iSOA to be more resistant to evaporation with the addition of $\mathrm{NO}_{x}$.

A sum thermogram of $\alpha$-pinene ozonolysis that has been previously reported (Lopez-Hilfiker et al., 2015) is displayed alongside those of the low- and high- $\mathrm{NO}_{x}$ experiments (Fig. 7, top) for comparison. The $\alpha$-pinene SOA has a bimodal sum thermogram, similar to that of the high$\mathrm{NO}_{x}$ iSOA, with the second lower-volatility modes in the same temperature range. The higher-volatility mode of the $\alpha$-pinene SOA corresponds in temperature space to that of the higher-volatility mode of the low- $\mathrm{NO}_{x}$ iSOA. The multiple modes of the $\alpha$-pinene sum thermogram have the same relative maxima in signal space, unlike the isoprene sum thermograms. $\alpha$-Pinene ozonolysis apparently generates a larger fraction of lower-volatility SOA relative to isoprene photo- 
chemical oxidation, although isoprene photochemical SOA has components in the same volatility ranges of $\alpha$-pinene ozonolysis SOA, and the relative size of the various modes and location in temperature space is dependent on the amount of $\mathrm{NO}_{x}$.

The contribution of the effectively lower-volatility components inferred from thermograms in Fig. 7 is likely underestimated in both the low- and high- $\mathrm{NO}_{x}$ cases because the thermograms are presented as ion signal not mass concentration. If we converted into mass concentration units prior to calculating the summed thermogram, the contribution of $\mathrm{C}_{5} \mathrm{H}_{12} \mathrm{O}_{6}$ would be significantly less than implied in Fig. 7. The integrated contribution of $\mathrm{C}_{5} \mathrm{H}_{12} \mathrm{O}_{6}$ would instead be more similar to that shown in Fig. 4 for which we applied calibration estimates based on ISOPOOH and a range of other oxygenated compounds, together with the ion-molecule collision-limited sensitivity discussed previously (Liu et al., 2016; Lopez-Hilfiker et al., 2016a). In conclusion, the low- $\mathrm{NO}_{x}$ SOA has an overall higher volatility and the addition of $\mathrm{NO}_{x}$ results in lower-volatility material making up a larger fraction of the SOA, although the total SOA yield is lower (Liu et al., 2016), in general agreement with previous studies showing that increasing $\mathrm{NO}_{x}$ leads to lower-volatility SOA (Kleindienst et al., 2009), likely by enhancing oligomerization (Dommen et al., 2006; Xu et al., 2014; Nguyen et al., 2015). However, many of these previous studies were carried out in very different concentration regimes with different detection techniques, so that the data we present offers an additional contribution to the general importance of oligomerization.

\section{Conclusions}

We have explored the composition and volatility of isoprene $\mathrm{SOA}$ at low- and high- $\mathrm{NO}_{x}$ concentrations, utilizing effloresced ammonium sulfate seed to prevent IEPOX uptake and thus suppress IEPOX multiphase chemistry. We measured compositions of products reported in previous works of similar experiments (Krechmer et al., 2015; Liu et al., 2016; Riva et al., 2016), in particular $\mathrm{C}_{5} \mathrm{H}_{12} \mathrm{O}_{6}$ and related highly oxidized compounds. We note that these compounds have also been observed in the atmosphere in isoprene-rich regions (Riva et al., 2016). We examined the saturation vapor concentrations of several of the most dominant particlephase signals and tested the accuracy of various groupcontribution methods in determining the $C^{*}$. Of the three group-contribution methods assessed, the SIMPOL approach (Pankow and Asher, 2008) gave the closest estimates of $C^{*}$ compared to those determined from the thermograms. The vapor pressure lowering effect of - $\mathrm{OOH}$ groups, assumed to be abundantly present in this system, appears to be greatly overestimated in two commonly used methods (Capouet and Muller, 2006; Compernolle et al., 2011). Through these analyses we found that a significant fraction of SOA compo- nents we measured are likely thermal decomposition fragments, characterized by broad thermograms and higher-thanexpected $T_{\max }$.

That such a large fraction (30-45\%) of the non-IEPOX iSOA is of low volatility implies that the lifetime of nonIEPOX iSOA is longer than would previously be expected. Together with the thermal decomposition fragments, we also observe compounds with six or greater carbons, supporting an important role for oligomerization chemistry. These findings suggest that experiments that assess the SOA formation potential of isoprene or one of its oxidation products alone likely underestimate the overall potential due to the participation of a broad suite of products in oligomerization chemistry. Further work on the role of oligomerization chemistry in this system is needed to verify that the higher iSOA yield observed by Liu et al. (2016) from isoprene is indeed caused by semivolatile products participating in oligomerization reactions. Furthermore, we show here that the addition of NO has a strong effect on the amount of $\mathrm{C}_{5} \mathrm{H}_{12} \mathrm{O}_{6}$ produced, and while the overall volatility of the OA decreases with $\mathrm{NO}_{x}$, the total amount of OA also decreases (Liu et al., 2016), indicating that in polluted regions the amount of SOA formed from this pathway will be diminished, but the SOA will be longer lived against dilution. In conclusion, due to the high yield of IEPOX from ISOPOOH $+\mathrm{OH}$, it has been assumed to be the most important pathway for the formation of iSOA; however, its relatively high volatility $\left(\sim 2 \times 10^{4} \mathrm{\mu g} \mathrm{m}^{-3}\right.$; Compernolle et al., 2011) and the fact that it requires such specific conditions to form SOA efficiently implies that the formation of SOA from the non-IEPOX pathway discussed herein can also play an important role in many environments regardless of sulfate aerosol concentrations.

Acknowledgements. This work was supported by the US Department of Energy ASR grants DE-SC0011791. Emma L. D'Ambro was supported by the National Science Foundation Graduate Research Fellowship under grant no. DGE-1256082. Ben H. Lee was supported by the National Oceanic and Atmospheric Administration (NOAA) Climate and Global Change Postdoctoral Fellowship Program. Frank N. Keutsch and Jean C. Rivera-Rios were supported by the National Science Foundation (AGS 1628491 and 1628530). PNNL authors were supported by the US Department of Energy, Office of Biological and Environmental Research as part of the ASR program. The Pacific Northwest National Laboratory is operated for DOE by Battelle Memorial Institute under contract DE-AC05-76RL01830. We thank J. D. Crounse for useful discussions.

Edited by: K. Tsigaridis

Reviewed by: two anonymous referees 


\section{References}

Baasandorj, M., Papanastasiou, D. K., Talukdar, R. K., Hasson, A. S., and Burkholder, J. B.: $\left(\mathrm{CH}_{3}\right)(3) \mathrm{COOH}$ (tert-butyl hydroperoxide): $\mathrm{OH}$ reaction rate coefficients between 206 and $375 \mathrm{~K}$ and the $\mathrm{OH}$ photolysis quantum yield at $248 \mathrm{~nm}$, Phys. Chem. Chem. Phys., 12, 12101-12111, doi:10.1039/c0cp00463d, 2010.

Capouet, M. and Müller, J.-F.: A group contribution method for estimating the vapour pressures of a-pinene oxidation products, Atmos. Chem. Phys., 6, 1455-1467, doi:10.5194/acp-6-1455-2006, 2006.

Claeys, M., Graham, B., Vas, G., Wang, W., Vermeylen, R., Pashynska, V., Cafmeyer, J., Guyon, P., Andreae, M. O., Artaxo, P., and Maenhaut, W.: Formation of secondary organic aerosols through photooxidation of isoprene, Science, 303, 1173-1176, doi:10.1126/science.1092805, 2004.

Compernolle, S., Ceulemans, K., and Müller, J.-F.: EVAPORATION: a new vapour pressure estimation methodfor organic molecules including non-additivity and intramolecular interactions, Atmos. Chem. Phys., 11, 9431-9450, doi:10.5194/acp-119431-2011, 2011.

Ding, X., Zheng, M., Yu, L. P., Zhang, X. L., Weber, R. J., Yan, B., Russell, A. G., Edgerton, E. S., and Wang, X. M.: Spatial and seasonal trends in biogenic secondary organic aerosol tracers and water-soluble organic carbon in the southeastern United States, Environ. Sci. Technol., 42, 5171-5176, doi:10.1021/es7032636, 2008.

Docherty, K. S., Wu, W., Lim, Y. B., and Ziemann, P. J.: Contributions of organic peroxides to secondary aerosol formed from reactions of monoterpenes with $\mathrm{O}_{3}$, Environ. Sci. Technol., 39, 4049-4059, doi:10.1021/es050228s, 2005.

Dommen, J., Metzger, A., Duplissy, J., Kalberer, M., Alfarra, M. R., Gascho, A., Weingartner, E., Prevot, A. S. H., Verheggen, B., and Baltensperger, U.: Laboratory observation of oligomers in the aerosol from isoprene/ $\mathrm{NO}_{x}$ photooxidation, Geophys. Res. Lett., 33, L13805, doi:10.1029/2006GL026523, 2006.

Donahue, N. M., Robinson, A. L., Stanier, C. O., and Pandis, S. N.: Coupled partitioning, dilution, and chemical aging of semivolatile organics, Environ. Sci. Technol., 40, 2635-2643, doi:10.1021/es052297c, 2006.

Donahue, N. M., Trump, E. R., Pierce, J. R., and Riipinen, I.: Theoretical constraints on pure vapor-pressure driven condensation of organics to ultrafine particles, Geophys. Res. Lett., 38, L16801, doi:10.1029/2011GL048115, 2011.

Edney, E. O., Kleindienst, T. E., Jaoui, M., Lewandowski, M., Offenberg, J. H., Wang, W., and Claeys, M.: Formation of 2methyl tetrols and 2-methylglyceric acid in secondary organic aerosol from laboratory irradiated isoprene/ $\mathrm{NO}_{x} / \mathrm{SO}_{2} /$ air mixtures and their detection in ambient $\mathrm{PM}_{2.5}$ samples collected in the eastern United States, Atmos. Environ., 39, 5281-5289, doi:10.1016/j.atmosenv.2005.05.031, 2005.

Gaston, C. J., Riedel, T. P., Zhang, Z. F., Gold, A., Surratt, J. D., and Thornton, J. A.: Reactive Uptake of an Isoprene-Derived Epoxydiol to Submicron Aerosol Particles, Environ. Sci. Technol., 48, 11178-11186, doi:10.1021/es5034266, 2014.

Gaston, C. J., Lopez-Hilfiker, F. D., Whybrew, L. E., Hadley, O., McNair, F., Gao, H., Jaffe, D. A., and Thornton, J. A.: Online molecular characterization of fine particulate matter in Port Angeles, WA: Evidence for a major impact from residential wood smoke, Atmos. Environ., 138, 99-107, doi:10.1016/j.atmosenv.2016.05.013, 2016.

Guenther, A. B., Jiang, X., Heald, C. L., Sakulyanontvittaya, T., Duhl, T., Emmons, L. K., and Wang, X.: The Model of Emissions of Gases and Aerosols from Nature version 2.1 (MEGAN2.1): an extended and updated framework for modeling biogenic emissions, Geosci. Model Dev., 5, 1471-1492, doi:10.5194/gmd-51471-2012, 2012.

Hsieh, S., Vushe, R., Tun, Y. M. T., and Vallejo, J. L.: Trends in organic hydroperoxide photodissociation and absorption cross sections between 266 and $377 \mathrm{~nm}$, Chem. Phys. Lett., 591, 99-102, doi:10.1016/j.cplett.2013.11.008, 2014.

Jacobs, M. I., Burke, W. J., and Elrod, M. J.: Kinetics of the reactions of isoprene-derived hydroxynitrates: gas phase epoxide formation and solution phase hydrolysis, Atmos. Chem. Phys., 14, 8933-8946, doi:10.5194/acp-14-8933-2014, 2014.

Jang, M. S., Czoschke, N. M., Lee, S., and Kamens, R. M.: Heterogeneous atmospheric aerosol production by acidcatalyzed particle-phase reactions, Science, 298, 814-817, doi:10.1126/science.1075798, 2002.

Jathar, S. H., Cappa, C. D., Wexler, A. S., Seinfeld, J. H., and Kleeman, M. J.: Simulating secondary organic aerosol in a regional air quality model using the statistical oxidation model - Part 1: Assessing the influence of constrained multi-generational ageing, Atmos. Chem. Phys., 16, 2309-2322, doi:10.5194/acp-162309-2016, 2016.

Jimenez, J. L., Canagaratna, M. R., Donahue, N. M., Prevot, A. S. H., Zhang, Q., Kroll, J. H., DeCarlo, P. F., Allan, J. D., Coe, H., Ng, N. L., Aiken, A. C., Docherty, K. S., Ulbrich, I. M., Grieshop, A. P., Robinson, A. L., Duplissy, J., Smith, J. D., Wilson, K. R., Lanz, V. A., Hueglin, C., Sun, Y. L., Tian, J., Laaksonen, A., Raatikainen, T., Rautiainen, J., Vaattovaara, P., Ehn, M., Kulmala, M., Tomlinson, J. M., Collins, D. R., Cubison, M. J., Dunlea, E. J., Huffman, J. A., Onasch, T. B., Alfarra, M. R., Williams, P. I., Bower, K., Kondo, Y., Schneider, J., Drewnick, F., Borrmann, S., Weimer, S., Demerjian, K., Salcedo, D., Cottrell, L., Griffin, R., Takami, A., Miyoshi, T., Hatakeyama, S., Shimono, A., Sun, J. Y., Zhang, Y. M., Dzepina, K., Kimmel, J. R., Sueper, D., Jayne, J. T., Herndon, S. C., Trimborn, A. M., Williams, L. R., Wood, E. C., Middlebrook, A. M., Kolb, C. E., Baltensperger, U., and Worsnop, D. R.: Evolution of Organic Aerosols in the Atmosphere, Science, 326, 1525-1529, doi:10.1126/science.1180353, 2009.

King, S. M., Rosenoern, T., Shilling, J. E., Chen, Q., Wang, Z., Biskos, G., McKinney, K. A., Pöschl, U., and Martin, S. T.: Cloud droplet activation of mixed organic-sulfate particles produced by the photooxidation of isoprene, Atmos. Chem. Phys., 10, 3953-3964, doi:10.5194/acp-10-3953-2010, 2010.

Kirkby, J., Duplissy, J., Sengupta, K., Frege, C., Gordon, H., Williamson, C., Heinritzi, M., Simon, M., Yan, C., Almeida, J., Trostl, J., Nieminen, T., Ortega, I. K., Wagner, R., Adamov, A., Amorim, A., Bernhammer, A. K., Bianchi, F., Breitenlechner, M., Brilke, S., Chen, X. M., Craven, J., Dias, A., Ehrhart, S., Flagan, R. C., Franchin, A., Fuchs, C., Guida, R., Hakala, J., Hoyle, C. R., Jokinen, T., Junninen, H., Kangasluoma, J., Kim, J., Krapf, M., Kurten, A., Laaksonen, A., Lehtipalo, K., Makhmutov, V., Mathot, S., Molteni, U., Onnela, A., Perakyla, O., Piel, F., Petaja, T., Praplan, A. P., Pringle, K., Rap, A., Richards, N. A. D., Riipinen, I., Rissanen, M. P., Rondo, L., Sarnela, N., Schobesberger, 
S., Scott, C. E., Seinfeld, J. H., Sipila, M., Steiner, G., Stozhkov, Y., Stratmann, F., Tome, A., Virtanen, A., Vogel, A. L., Wagner, A. C., Wagner, P. E., Weingartner, E., Wimmer, D., Winkler, P. M., Ye, P. L., Zhang, X., Hansel, A., Dommen, J., Donahue, N. M., Worsnop, D. R., Baltensperger, U., Kulmala, M., Carslaw, K. S., and Curtius, J.: Ion-induced nucleation of pure biogenic particles, Nature, 533, 521-526, doi:10.1038/nature17953, 2016.

Kleindienst, T. E., Lewandowski, M., Offenberg, J. H., Jaoui, M., and Edney, E. O.: The formation of secondary organic aerosol from the isoprene $+\mathrm{OH}$ reaction in the absence of $\mathrm{NO}_{x}$, Atmos. Chem. Phys., 9, 6541-6558, doi:10.5194/acp-9-6541-2009, 2009.

Kourtchev, I., Ruuskanen, T., Maenhaut, W., Kulmala, M., and Claeys, M.: Observation of 2-methyltetrols and related photo-oxidation products of isoprene in boreal forest aerosols from Hyytiälä, Finland, Atmos. Chem. Phys., 5, 2761-2770, doi:10.5194/acp-5-2761-2005, 2005.

Krechmer, J. E., Coggon, M. M., Massoli, P., Nguyen, T. B., Crounse, J. D., Hu, W. W., Day, D. A., Tyndall, G. S., Henze, D. K., Rivera-Rios, J. C., Nowak, J. B., Kimmel, J. R., Mauldin, R. L., Stark, H., Jayne, J. T., Sipila, M., Junninen, H., Clair, J. M. S., Zhang, X., Feiner, P. A., Zhang, L., Miller, D. O., Brune, W. H., Keutsch, F. N., Wennberg, P. O., Seinfeld, J. H., Worsnop, D. R., Jimenez, J. L., and Canagaratna, M. R.: Formation of Low Volatility Organic Compounds and Secondary Organic Aerosol from Isoprene Hydroxyhydroperoxide Low-NO Oxidation, Environ. Sci. Technol., 49, 10330-10339, doi:10.1021/acs.est.5b02031, 2015.

Kroll, J. H., Ng, N. L., Murphy, S. M., Flagan, R. C., and Seinfeld, J. H.: Secondary organic aerosol formation from isoprene photooxidation under high- $\mathrm{NO}_{x}$ conditions, Geophys. Res. Lett., 32, L18808, doi:10.1029/2005GL023637, 2005.

Kroll, J. H., Ng, N. L., Murphy, S. M., Flagan, R. C., and Seinfeld, J. H.: Secondary organic aerosol formation from isoprene photooxidation, Environ. Sci. Technol., 40, 1869-1877, doi:10.1021/es0524301, 2006.

Kurten, T., Tiusanen, K., Roldin, P., Rissanen, M., Luy, J. N., Boy, M., Ehn, M., and Donahue, N.: alpha-Pinene Autoxidation Products May Not Have Extremely Low Saturation Vapor Pressures Despite High O : C Ratios, J. Phys. Chem. A, 120, 2569-2582, doi:10.1021/acs.jpca.6b02196, 2016.

Lane, T. E., Donahue, N. M., and Pandis, S. N.: Effect of $\mathrm{NO}_{x}$ on secondary organic aerosol concentrations, Environ. Sci. Technol., 42, 6022-6027, doi:10.1021/es703225a, 2008.

Lee, B. H., Lopez-Hilfiker, F. D., Mohr, C., Kurten, T., Worsnop, D. R., and Thornton, J. A.: An iodide-adduct high-resolution time-of-flight chemical-ionization mass spectrometer: application to atmospheric inorganic and organic compounds, Environ. Sci. Technol., 48, 6309-6317, doi:10.1021/es500362a, 2014.

Lee, B. H., Mohr, C., Lopez-Hilfiker, F. D., Lutz, A., Hallquist, M., Lee, L., Romer, P., Cohen, R. C., Iyer, S., Kurtén, T., Hu, W., Day, D. A., Campuzano-Jost, P., Jimenez, J. L., Xu, L., Ng, N. L., Guo, H., Weber, R. J., Wild, R. J., Brown, S. S., Koss, A., de Gouw, J., Olson, K., Goldstein, A. H., Seco, R., Kim, S., McAvey, K., Shepson, P. B., Starn, T., Baumann, K., Edgerton, E. S., Liu, J., Shilling, J. E., Miller, D. O., Brune, W., Schobesberger, S., D'Ambro, E. L., and Thornton, J. A.: Highly functionalized organic nitrates in the southeast United States: Contribution to secondary organic aerosol and reactive nitrogen budgets, P. Natl.
Acad. Sci. USA, 113, 1516-1521 doi:10.1073/pnas.1508108113, 2016.

Lee, L., Teng, A. P., Wennberg, P. O., Crounse, J. D., and Cohen, R. C.: On rates and mechanisms of $\mathrm{OH}$ and $\mathrm{O}_{3}$ reactions with isoprene-derived hydroxy nitrates, J. Phys. Chem. A, 118, 16221637, doi:10.1021/jp4107603, 2014.

Lin, Y.-H., Zhang, Z. F., Docherty, K. S., Zhang, H. F., Budisulistiorini, S. H., Rubitschun, C. L., Shaw, S. L., Knipping, E. M., Edgerton, E. S., Kleindienst, T. E., Gold, A., and Surratt, J. D.: Isoprene Epoxydiols as Precursors to Secondary Organic Aerosol Formation: Acid-Catalyzed Reactive Uptake Studies with Authentic Compounds, Environ. Sci. Technol., 46, 250258, doi:10.1021/es202554c, 2012.

Lin, Y.-H., Knipping, E. M., Edgerton, E. S., Shaw, S. L., and Surratt, J. D.: Investigating the influences of $\mathrm{SO}_{2}$ and $\mathrm{NH}_{3}$ levels on isoprene-derived secondary organic aerosol formation using conditional sampling approaches, Atmos. Chem. Phys., 13, 84578470, doi:10.5194/acp-13-8457-2013, 2013a.

Lin, Y.-H., Zhang, H. F., Pye, H. O. T., Zhang, Z. F., Marth, W. J., Park, S., Arashiro, M., Cui, T. Q., Budisulistiorini, H., Sexton, K. G., Vizuete, W., Xie, Y., Luecken, D. J., Piletic, I. R., Edney, E. O., Bartolotti, L. J., Gold, A., and Surratt, J. D.: Epoxide as a precursor to secondary organic aerosol formation from isoprene photooxidation in the presence of nitrogen oxides, P. Natl. Acad. Sci. USA, 110, 6718-6723, doi:10.1073/pnas.1221150110, 2013 b.

Lin, Y.-H., Budisulistiorini, H., Chu, K., Siejack, R. A., Zhang, H. F., Riva, M., Zhang, Z. F., Gold, A., Kautzman, K. E., and Surratt, J. D.: Light-Absorbing Oligomer Formation in Secondary Organic Aerosol from Reactive Uptake of Isoprene Epoxydiols, Environ. Sci. Technol., 48, 12012-12021, doi:10.1021/es503142b, 2014.

Liu, J. M., D’Ambro, E. L., Lee, B. H., Lopez-Hilfiker, F. D., Zaveri, R. A., Rivera-Rios, J. C., Keutsch, F. N., Iyer, S., Kurten, T., Zhang, Z. F., Gold, A., Surratt,J. D., Shilling, J. E., and Thornton, J. A.: Efficient Isoprene Secondary Organic Aerosol Formation from a Non-IEPOX Pathway, Environ. Sci. Technol., 50, 98729880, doi:10.1021/acs.est.6b01872, 2016.

Liu, S., Shilling, J. E., Song, C., Hiranuma, N., Zaveri, R. A., and Russell, L. M.: Hydrolysis of Organonitrate Functional Groups in Aerosol Particles, Aerosol Sci. Technol., 46, 1359-1369, doi:10.1080/02786826.2012.716175, 2012.

Liu, Y., Kuwata, M., Strick, B. F., Geiger, F. M., Thomson, R. J., McKinney, K. A., and Martin, S. T.: Uptake of Epoxydiol Isomers Accounts for Half of the Particle-Phase Material Produced from Isoprene Photooxidation via the HO Pathway, Environ. Sci. Technol., 49, 250-258, doi:10.1021/es5034298, 2014.

Lopez-Hilfiker, F. D., Mohr, C., Ehn, M., Rubach, F., Kleist, E., Wildt, J., Mentel, Th. F., Lutz, A., Hallquist, M., Worsnop, D., and Thornton, J. A.: A novel method for online analysis of gas and particle composition: description and evaluation of a Filter Inlet for Gases and AEROsols (FIGAERO), Atmos. Meas. Tech., 7, 983-1001, doi:10.5194/amt-7-983-2014, 2014.

Lopez-Hilfiker, F. D., Mohr, C., Ehn, M., Rubach, F., Kleist, E., Wildt, J., Mentel, Th. F., Carrasquillo, A. J., Daumit, K. E., Hunter, J. F., Kroll, J. H., Worsnop, D. R., and Thornton, J. A.: Phase partitioning and volatility of secondary organic aerosol components formed from $\alpha$-pinene ozonolysis and $\mathrm{OH}$ oxidation: the importance of accretion products and other 
low volatility compounds, Atmos. Chem. Phys., 15, 7765-7776, doi:10.5194/acp-15-7765-2015, 2015.

Lopez-Hilfiker, F. D., Iyer, S., Mohr, C., Lee, B. H., D’ Ambro, E. L., Kurtén, T., and Thornton, J. A.: Constraining the sensitivity of iodide adduct chemical ionization mass spectrometry to multifunctional organic molecules using the collision limit and thermodynamic stability of iodide ion adducts, Atmos. Meas. Tech., 9, 1505-1512, doi:10.5194/amt-9-1505-2016, 2016 a.

Lopez-Hilfiker, F. D., Mohr, C., D’Ambro, E. L., Lutz, A., Riedel, T. P., Gaston, C. J., Iyer, S., Zhang, Z., Gold, A., Surratt, J. D., Lee, B. H., Kurten, T., Hu, W. W., Jimenez, J., Hallquist, M., and Thornton, J. A.: Molecular Composition and Volatility of Organic Aerosol in the Southeastern US: Implications for IEPOX Derived SOA, Environ. Sci. Technol., 50, 2200-2209, doi:10.1021/acs.est.5b04769, 2016b.

Nannoolal, Y., Rarey, J., and Ramjugernath, D.: Estimation of pure component properties - Part 3: Estimation of the vapor pressure of non-electrolyte organic compounds via group contributions and group interactions, Fluid Phase Equilibr., 269, 117133, doi:10.1016/j.fluid.2008.04.020, 2008.

Nguyen, T. B., Coggon, M. M., Bates, K. H., Zhang, X., Schwantes, R. H., Schilling, K. A., Loza, C. L., Flagan, R. C., Wennberg, P. O., and Seinfeld, J. H.: Organic aerosol formation from the reactive uptake of isoprene epoxydiols (IEPOX) onto nonacidified inorganic seeds, Atmos. Chem. Phys., 14, 3497-3510, doi:10.5194/acp-14-3497-2014, 2014.

Nguyen, T. B., Bates, K. H., Crounse, J. D., Schwantes, R. H., Zhang, X., Kjaergaard, H. G., Surratt, J. D., Lin, P., Laskin, A., Seinfeld, J. H., and Wennberg, P. O.: Mechanism of the hydroxyl radical oxidation of methacryloyl peroxynitrate (MPAN) and its pathway toward secondary organic aerosol formation in the atmosphere, Phys. Chem. Chem. Phys., 17, 17914-17926, doi:10.1039/c5cp02001h, 2015.

Pandis, S. N., Paulson, S. E., Seinfeld, J. H., and Flagan, R. C.: Aerosol formation in the photooxidation of isoprene and betapinene, Atmos. Environ. A, 25, 997-1008, doi:10.1016/09601686(91)90141-s, 1991.

Pankow, J. F.: An absorption-model of gas-particle partitioning of organic-compounds in the atmosphere, Atmos. Environ., 28, 185-188, doi:10.1016/1352-2310(94)90093-0, 1994.

Pankow, J. F. and Asher, W. E.: SIMPOL.1: a simple group contribution method for predicting vapor pressures and enthalpies of vaporization of multifunctional organic compounds, Atmos. Chem. Phys., 8, 2773-2796, doi:10.5194/acp-8-27732008, 2008.

Paulot, F., Crounse, J. D., Kjaergaard, H. G., Kroll, J. H., Seinfeld, J. H., and Wennberg, P. O.: Isoprene photooxidation: new insights into the production of acids and organic nitrates, Atmos. Chem. Phys., 9, 1479-1501, doi:10.5194/acp-9-1479-2009, 2009a.

Paulot, F., Crounse, J. D., Kjaergaard, H. G., Kurten, A., St Clair, J. M., Seinfeld, J. H., and Wennberg, P. O.: Unexpected Epoxide Formation in the Gas-Phase Photooxidation of Isoprene, Science, 325, 730-733, doi:10.1126/science.1172910, 2009 b.

Pöschl, U.: Atmospheric aerosols: Composition, transformation, climate and health effects, Angew. Chem.-Int. Edit., 44, 75207540, doi:10.1002/anie.200501122, 2005.

Riedel, T. P., Lin, Y. H., Budisulistiorini, H., Gaston, C. J., Thornton, J. A., Zhang, Z. F., Vizuete, W., Gold, A., and Surratt, J. D.: Heterogeneous Reactions of Isoprene-Derived
Epoxides: Reaction Probabilities and Molar Secondary Organic Aerosol Yield Estimates, Environ. Sci. Technol. Lett., 2, 38-42, doi:10.1021/ez500406f, 2015.

Riipinen, I., Pierce, J. R., Yli-Juuti, T., Nieminen, T., Hakkinen, S., Ehn, M., Junninen, H., Lehtipalo, K., Petaja, T., Slowik, J., Chang, R., Shantz, N. C., Abbatt, J., Leaitch, W. R., Kerminen, V. M., Worsnop, D. R., Pandis, S. N., Donahue, N. M., and Kulmala, M.: Organic condensation: a vital link connecting aerosol formation to cloud condensation nuclei $(\mathrm{CCN})$ concentrations, Atmos. Chem. Phys., 11, 3865-3878, doi:10.5194/acp-11-38652011, 2011.

Riva, M., Budisulistiorini, S. H., Chen, Y. Z., Zhang, Z. F., D’Ambro, E. L., Zhang, X., Gold, A., Turpin, B. J., Thornton, J. A., Canagaratna, M. R., and Surratt, J. D.: Chemical Characterization of Secondary Organic Aerosol from Oxidation of Isoprene Hydroxyhydroperoxides, Environ. Sci. Technol., 50, 9889-9899, doi:10.1021/acs.est.6b02511, 2016.

Roehl, C. M., Marka, Z., Fry, J. L., and Wennberg, P. O.: Near-UV photolysis cross sections of $\mathrm{CH}_{3} \mathrm{OOH}$ and $\mathrm{HOCH}_{2} \mathrm{OOH}$ determined via action spectroscopy, Atmos. Chem. Phys., 7, 713-720, doi:10.5194/acp-7-713-2007, 2007.

Sato, K., Nakao, S., Clark, C. H., Qi, L., and Cocker III, D. R.: Secondary organic aerosol formation from the photooxidation of isoprene, 1,3-butadiene, and 2,3-dimethyl-1,3-butadiene under high $\mathrm{NO}_{x}$ conditions, Atmos. Chem. Phys., 11, 7301-7317, doi:10.5194/acp-11-7301-2011, 2011.

Shilling, J. E., Chen, Q., King, S. M., Rosenoern, T., Kroll, J. H., Worsnop, D. R., McKinney, K. A., and Martin, S. T.: Particle mass yield in secondary organic aerosol formed by the dark ozonolysis of $\alpha$-pinene, Atmos. Chem. Phys., 8, 2073-2088, doi:10.5194/acp-8-2073-2008, 2008.

Shilling, J. E., Zaveri, R. A., Fast, J. D., Kleinman, L., Alexander, M. L., Canagaratna, M. R., Fortner, E., Hubbe, J. M., Jayne, J. T., Sedlacek, A., Setyan, A., Springston, S., Worsnop, D. R., and Zhang, Q.: Enhanced SOA formation from mixed anthropogenic and biogenic emissions during the CARES campaign, Atmos. Chem. Phys., 13, 2091-2113, doi:10.5194/acp-13-20912013, 2013.

St. Clair, J. M., Rivera-Rios, J. C., Crounse, J. D., Knap, H. C., Bates, K. H., Teng, A. P., Jorgensen, S., Kjaergaard, H. G., Keutsch, F. N., and Wennberg, P. O.: Kinetics and Products of the Reaction of the First-Generation Isoprene Hydroxy Hydroperoxide (ISOPOOH) with OH, J. Phys. Chem. A, 120, 1441-1451, doi:10.1021/acs.jpca.5b06532, 2016.

Surratt, J. D., Murphy, S. M., Kroll, J. H., Ng, N. L., Hildebrandt, L., Sorooshian, A., Szmigielski, R., Vermeylen, R., Maenhaut, W., Claeys, M., Flagan, R. C., and Seinfeld, J. H.: Chemical composition of secondary organic aerosol formed from the photooxidation of isoprene, J. Phys. Chem. A, 110, 9665-9690, doi:10.1021/jp061734m, 2006.

Surratt, J. D., Lewandowski, M., Offenberg, J. H., Jaoui, M., Kleindienst, T. E., Edney, E. O., and Seinfeld, J. H.: Effect of acidity on secondary organic aerosol formation from isoprene, Environ. Sci. Technol., 41, 5363-5369, doi:10.1021/es0704176, 2007.

Surratt, J. D., Chan, A. W. H., Eddingsaas, N. C., Chan, M. N., Loza, C. L., Kwan, A. J., Hersey, S. P., Flagan, R. C., Wennberg, P. O., and Seinfeld, J. H.: Reactive intermediates revealed in secondary organic aerosol formation 
from isoprene, P. Natl. Acad. Sci. USA, 107, 6640-6645, doi:10.1073/pnas.0911114107, 2010.

Tsai, I. C., Chen, J. P., Lung, C. S. C., N. Li, Chen, W. N., Fu, T. M., Chang, C. C., and Hwang, G. D.: Sources and formation pathways of organic aerosol in a subtropical metropolis during summer, Atmos. Environ., 117, 51-60, doi:10.1016/j.atmosenv.2015.07.005, 2015.

Valorso, R., Aumont, B., Camredon, M., Raventos-Duran, T., Mouchel-Vallon, C., Ng, N. L., Seinfeld, J. H., Lee-Taylor, J., and Madronich, S.: Explicit modelling of SOA formation from $\alpha$-pinene photooxidation: sensitivity to vapour pressure estimation, Atmos. Chem. Phys., 11, 6895-6910, doi:10.5194/acp-116895-2011, 2011.

Weber, R. J., Sullivan, A. P., Peltier, R. E., Russell, A., Yan, B., Zheng, M., de Gouw, J., Warneke, C., Brock, C., Holloway, J. S., Atlas, E. L., and Edgerton, E.: A study of secondary organic aerosol formation in the anthropogenic-influenced southeastern United States, J. Geophys. Res.-Atmos., 112, D13302, doi:10.1029/2007JD008408, 2007.

Xia, X. and Hopke, P. K.: Seasonal variation of 2-methyltetrols in ambient air samples, Environ. Sci. Technol., 40, 6934-6937, doi:10.1021/es060988i, 2006.

Xu, L., Kollman, M. S., Song, C., Shilling, J. E., and Ng, N. L.: Effects of $\mathrm{NO}_{x}$ on the volatility of secondary organic aerosol from isoprene photooxidation, Environ. Sci. Technol., 48, 22532262, doi:10.1021/es404842g, 2014.

Xu, L., Guo, H. Y., Boyd, C. M., Klein, M., Bougiatioti, A., Cerully, K. M., Hite, J. R., Isaacman-VanWertz, G., Kreisberg, N. M., Knote, C., Olson, K., Koss, A., Goldstein, A. H., Hering, S. V., de Gouw, J., Baumann, K., Lee, S. H., Nenes, A., Weber, R. J., and $\mathrm{Ng}$, N. L.: Effects of anthropogenic emissions on aerosol formation from isoprene and monoterpenes in the southeastern United States, P. Natl. Acad. Sci. USA, 112, 37-42, doi:10.1073/pnas.1417609112, 2015.
Zhang, H., Surratt, J. D., Lin, Y. H., Bapat, J., and Kamens, R. M.: Effect of relative humidity on SOA formation from isoprene/NO photooxidation: enhancement of 2-methylglyceric acid and its corresponding oligoesters under dry conditions, Atmos. Chem. Phys., 11, 6411-6424, doi:10.5194/acp-11-6411-2011, 2011.

Zhang, Q., Jimenez, J. L., Canagaratna, M. R., Allan, J. D., Coe, H., Ulbrich, I., Alfarra, M. R., Takami, A., Middlebrook, A. M., Sun, Y. L., Dzepina, K., Dunlea, E., Docherty, K., DeCarlo, P. F., Salcedo, D., Onasch, T., Jayne, J. T., Miyoshi, T., Shimono, A., Hatakeyama, S., Takegawa, N., Kondo, Y., Schneider, J., Drewnick, F., Borrmann, S., Weimer, S., Demerjian, K., Williams, P., Bower, K., Bahreini, R., Cottrell, L., Griffin, R. J., Rautiainen, J., Sun, J. Y., Zhang, Y. M., and Worsnop, D. R.: Ubiquity and dominance of oxygenated species in organic aerosols in anthropogenically-influenced Northern Hemisphere midlatitudes, Geophys. Res. Lett., 34, L13801, doi:10.1029/2007GL029979, 2007.

Zhang, X., Cappa, C. D., Jathar, S. H., McVay, R. C., Ensberg, J. J., Kleeman, M. J., and Seinfeld, J. H.: Influence of vapor wall loss in laboratory chambers on yields of secondary organic aerosol, P. Natl. Acad. Sci. USA, 111, 5802-5807, doi:10.1073/pnas.1404727111, 2014. 